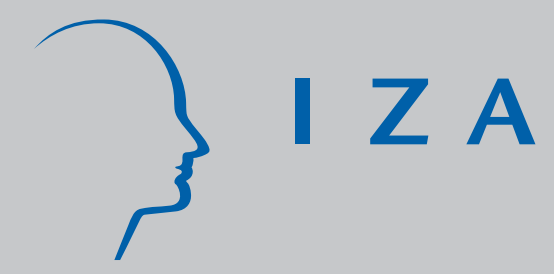

IZA DP No. 1429

On the Returns to Training in Portugal

Santiago Budría

Pedro Telhado Pereira

December 2004 


\title{
On the Returns to Training in Portugal
}

\author{
Santiago Budría \\ University of Madeira and CEEApIA \\ Pedro Telhado Pereira \\ University of Madeira, \\ CEPR, CEEAPIA and IZA Bonn
}

Discussion Paper No. 1429
December 2004

\author{
IZA \\ P.O. Box 7240 \\ 53072 Bonn \\ Germany \\ Phone: +49-228-3894-0 \\ Fax: +49-228-3894-180 \\ Email: iza@iza.org
}

Any opinions expressed here are those of the author(s) and not those of the institute. Research disseminated by IZA may include views on policy, but the institute itself takes no institutional policy positions.

The Institute for the Study of Labor (IZA) in Bonn is a local and virtual international research center and a place of communication between science, politics and business. IZA is an independent nonprofit company supported by Deutsche Post World Net. The center is associated with the University of Bonn and offers a stimulating research environment through its research networks, research support, and visitors and doctoral programs. IZA engages in (i) original and internationally competitive research in all fields of labor economics, (ii) development of policy concepts, and (iii) dissemination of research results and concepts to the interested public.

IZA Discussion Papers often represent preliminary work and are circulated to encourage discussion. Citation of such a paper should account for its provisional character. A revised version may be available directly from the author. 
IZA Discussion Paper No. 1429

December 2004

\section{ABSTRACT}

\section{On the Returns to Training in Portugal ${ }^{*}$}

This paper investigates the earnings effects of training in the Portuguese labour market. We use the Portuguese Labour Force Survey to classify training according to multiple criteria, including providing institution, purpose, duration, and content of the training activity. First, we establish some stylised facts about the extent and determinants of different types of training. We find that there are major differences in training participation across groups, with elder, low educated workers participating substantially less. Second, we measure the wage effects of training. We find that in Portugal returns to training are large and significant. The estimated coefficients are about $12 \%$ in the case of men and $37 \%$ in the case of women. We show that discriminating between gender, education level, experience, the public and the private sector, and industrial activity reveals important differences across categories of workers. Workers with low qualifications and long professional experience earn larger returns. On average, women receive larger returns than men, though they are subject to greater variation across education and experience groups. The average effect of training is similar in the private sector and in the public sector. Experience in the private sector and education in the public sector are key determinants of the returns to training. Further, training to improve current skills and training in a firm attract largest returns. Third, the paper investigates whether and to what extent training participation affects the probability of entering and leaving unemployment. We find that being trained does not affect significantly the transition probabilities.

JEL Classification: J7, J24, J31, 12

Keywords: returns to training, selection bias, logistic regression

Corresponding author:

Santiago Budría

Departamento de Gestão e Economia

Campus Universitário da Penteada

9000-390 Funchal

Madeira

Portugal

Email: sbudria@uma.pt

\footnotetext{
* We gratefully acknowledge the financial support of the European Commission, EDWIN project, HPSE-CT-2002-00108. We thank participants in the seminars of the UAB Department of Economics, the EALE 2004, and the SPIE 2004 conferences for helpful comments. We also thank Rita Asplund, Ali Skalli, Earling Barth, Crispin Clander, Peter Dolton and Panos Tsakloglou for stimulating suggestions.
} 


\section{Introduction and Executive Summary}

Education is a particularly scarce and valuable good in the Portuguese labour market. Among EU State Members, Portugal is the country with the lowest average schooling levels, while returns to formal education are highest (e.g., Vieira, 1999, and Pereira and Martins, 2002, inter alia). However, little is still known about the wage effects of training. As stated by Lynch and Black (1998, p. 65), "...the traditional schooling system is not an option that many incumbent workers or firms use when facing the need to upgrade their skills. As a result, the provision (or non provision) of employerprovided training is a key factor determining how much and what kind of skill upgrading occurs within firms and across workers"1. In this paper, we explore the extent, determinants and wage impact of various forms of training across workers with different characteristics.

In Portugal, participation in training is rather low as compared to OECD countries (OECD, 1999, 2003a; Ok and Tergeist, 2003). Both public and private firms seem to offer little advantages to training participation to their employees who, on the other hand, may have little incentives to enroll into such activities. Low training coverage raises efficiency concerns. Skills obsolescence may lead to substantial costs in terms of labour productivity, skill deterioration and unemployment. This might be of particular importance in an economy with already low labor productivity that, moreover, is currently experiencing difficulties in converging to OECD levels after a decade of convergence ${ }^{2}$.

In the past few years, training activities financed by the European Union have been stepped up. For the 1994-1999 period, the budget of the European Social Fund (ESF) allocated to programmes of human resources and promotion of employment was ECU 2,178 million for Portugal. It was expected that, over those years, ESF assistance would allow the training of 350,000 persons per year. A new programming period started in 2000 and will end in 2006. For that period, the ESF will transfer new funds to co-finance, together with national public funds, mainstream training programmes ${ }^{3}$. The committed budget was Euro 1,548 million, which represents the second highest per capita use of this kind of fund among European countries. As regards implementation, however, we find that execution rates are being rather low $^{4}$. This fact is disturbing, as it indicates that an important opportunity to upgrade the skills of the Portuguese workforce is being lost.

Training participation raises also equity concerns. In most countries, training tends to be concentrated on more educated workers (OECD, 1999, 2003a; Ok and Tergeist, 2003). At the same time, the returns to formal education are remarkably high in Portugal, and the wage gap between high and low skilled workers is substantial. Thus, if training increases wages and is concentrated towards

\footnotetext{
${ }^{1}$ Quoted in Asplund (2004).

${ }^{2}$ See EUROSTAT (2004).

${ }^{3}$ The POEFDS (Portuguese Operational Program of Employment, Training and Social Development) has been recently launched to translate the European Union employment strategy into action. It operates through five sub-programmes: Initial training, Continuous training, Public administration, Employment policy, and Social development.

${ }^{4}$ See CGQCA (2004).
} 
individuals with more favourable labour market characteristics, lower training participation among specific groups of workers may deteriorate the labour market position of already disadvantaged individuals. Moreover, different forms of training may be associated to different returns, which drives an additional wedge between groups of workers that typically participate in different training schemes. Further, individuals that differ in gender, education, and professional background may obtain different benefits from training activities, thus warning policy makers that equality of provision does not assure equality of outcome.

In this paper, we explore the extent and determinants of training participation. With such analysis we intend to identify those groups of workers that seldomly get trained. To our eyes, they constitute a critical group for policies aimed to increase the overall training participation. In a second stage, we explore the wage effects of training. Our results indicate that training exerts a positive impact on wages, particularly among less educated workers. An adequate implementation and execution of future funds aimed to training programmes is, hence, of particular relevance. Ceteris paribus, policies oriented to increase overall training participation or participation among low qualifided workers are expected to improve the labour market position of the more needy and reduce wage inequality. The analysis of other outcomes associated to training, such as firm productivity, social returns, and job mobility are beyond the scope of this paper.

Up to date, the evidence for Portugal is scarce. Several studies have used international comparable data to analyze the determinants and effects of training participation in different countries (OECD, 1999, 2003a; Brunello, 2001; Arulampalam et al., 2003; Ok and Tergeist, 2003). However, due to the lack of appropriate data, these studies report typically little evidence on the Portuguese case. At the national level, Saraiva (1999) explores training participation and its impact on wages. His results suggest that training activities that take place in the firm raise wages. As opposite, programmes provided by other institutions such as training centers do not increase wages significantly. Hartog et al. (2000) use the European Community Household Panel to explore earnings differentials between participants and non-participants in training programmes. They find that differences are significant only for some types of vocational training.

A weakness of the earlier analysis is that they present estimated returns that are an average across all training participants. This is an important simplification since, as we show, variation in participation and returns to training across workers that differ in education background, professional experience, sector of employment, and gender can be large. By differentiating between different categories of workers we can obtain valuable information to assess policy choices related to skill formation, such as whether to encourage an overall increase in training levels or to attempt to redirect training investments toward groups in the workforce whose expected returns are larger or are currently receiving little training.

One non-pecuniary benefit of training is security of employment. Training participants may benefit from better job stability and a lower probability of unemployment. In such case, workers may 
have strong incentives to enroll into training programmes, irrespective of the expected wage gains. In this paper, we investigate whether trained individuals a more likely to i) obtain a job when they are unemployed, and ii) maintain a job when they are employed.

The structure of the paper is as follows. Section 1 presents the data set and the classifications of training that we use throughout the paper. Section 2 offers a background discussion to motivate the choice of the model and its functional form. We follow two alternative approaches: simple OLS estimation and a treatment effects model that controls for the endogeneity of training. Section 3 presents the empirical results. In a first stage, we draw on the logit model to identify patterns of unequal training provision across different worker groups. In a second stage, the results on the wage impact of training are presented. Section 4 models transitions from employment to unemployment and vice versa, and discusses the role of training. Section 5 presents the concluding remarks. The paper contains additionally two appendices. Appendix A contains the training questions of the Portuguese Labour Force Survey. Appendix B assess the robustness of our results to changes in the econometric specification.

\section{The Data}

We use the Portuguese Labour Force Survey (henceforth, IE, Inquerito ao Emprego). The IE is a quarterly survey of a representative sample of households in Portugal. Its sample size is about 45,000 individuals, and it has a rotating structure in which $1 / 6$ of the sample is dropped randomly in each quarter. Our analysis uses pooled data from 1998 to 2000.

The latest waves of the IE constitute a valuable dataset to study the wage effects of training ${ }^{5}$. It provides four different, mutually exclusive, classifications of training activities. This information allows us to estimate separately the returns to a wider range of training types than is usually the case in related studies. This is of crucial importance as it offers the possibility of identifying what types of training have a better reward in the Portuguese labour market. The IE asks individuals about their monthly net wage, age, education level, time when the first contract was obtained, sector of employment, type of contract, professional activity, hours worked, tenure, and region, among other variables. The key question about training is

- $\quad$ "Apart from formal schooling, have you completed any training scheme as a formation for a professional activity?"

\footnotetext{
${ }^{5}$ In 1998 the design of the IE was improved along several dimensions. Prior to that year, the wage variable was interval-coded, which forced the researcher to do distributional assumptions and deal with the problem of topcoding. Second, it provided a poorer description of the training activities, insofar as one of the classification criteria appearing thereafter was not included. Third, it had no information on the training activities of both workers with the lowest education level -which has not been amended after 1998- and workers with tertiary education.
} 
Most international surveys explicitly ask for training participation during the last months and disregard training activities that took place in the past. As opposite, the above question does not refer to a particular time period. Thus, individuals in our sample can report on a training activity that took place years ago. Moreover, we know the date when the training activity was finished.

As a shortcoming, the IE does not offer the possibility of reporting more than one training activity. This misses important information, insofar as workers may have participated in training more than once. Therefore, we will assume that workers report the information regarding the most important training activity in their working lives. Trained workers are then asked to classify their training activity according to four different criteria. We know where the training activity took place, its purpose, content, and whether or not it had duration longer than one year ${ }^{6}$.

Surprisingly, the IE misses the information about the training activities of individuals with the lowest education level -less than 4 years of primary education. This is unfortunate, and forces us to restrict our sample to workers with the following highest qualification: between 4 and 6 years of primary education, 9 years of primary education -which in Portugal corresponds to completed compulsory education-, secondary, and tertiary education ${ }^{7}$.

As a second restriction, we leave out from the analysis workers that after having finished their training activities switched to a different job. The focus of our study is, therefore, the wage impact at the current job of training activities that took place after the job was obtained, rather than the impact of training activities that took place before the worker switched to his current job ${ }^{8}$. We further restrict our analysis to individuals who, at the time of the survey, were aged between 16 and 60, wage earners during the week of the interview, worked more than 15 hours a week, and were not employed in agricultural, fishing or extracting activities. Hence, we exclude self-employed individuals, as well as those whose main activity status is paid apprenticeship or training, unpaid family worker, out of the labour force and unemployed.

The previous exclusions leave us with a final sample of 27,001 individuals. Table 1 offers descriptive statistics of the raw data. The second column reports the proportion of trained workers within each population group. Only $8.4 \%$ of the sample population has ever participated in some

\footnotetext{
${ }^{6}$ The precise form of the training questions is given in Appendix A.

${ }^{7}$ Workers with 4 years or less education represent only $4.6 \%$ of the Portuguese workforce. Thus, restricting the sample to workers with more than 4 years of education is not expected to be affect the representativity of our results by much.

${ }^{8}$ Returns to training may differ importantly between workers that switch to a different job and workers that stay at the same job after having finished training. More barganining power, realized gains, and promotions are expected to increase the returns for moving workers. This is a dimension that we do not explore. The reason is that our data set does not provide us with good instruments in order to account for training participation among workers that switched to a different job. The only information available regards the employee's current job. Variables observed at the time of the survey such as activity, type of the contract, tenure, firm size, sector, and the like can hardly account for training participation in a former job and, therefore, we prefer to drop moving workers from the analysis.
} 
training activity. This rate places Portugal as one of the European countries with the lowest proportion of trained workers ${ }^{9}$.

\section{Training Location}

Respondents are asked to specify where the training activity took place, using five mutually exclusive categories: (i) higher or further education college, (ii) firm, (iii) training center, (iv) vocational school, and (v) unspecified locations. We use this information to differentiate between internal training and external training, depending on whether the training activity took place in the firm or in some other institution.

Panel A of Table 2 reports the proportions of each event. The distribution of training is quite evenly distributed across firms (31.8\% among men and 22.4\% among women), professional schools (about 21-23\%), and centres of professional formation (about 18-21\%), while training at a college or university has an incidence of less than $5 \%$. Thus, the main gender difference is that men are more likely to receive training at the firm than women.

\section{Training Purpose}

The purpose of the training activity must be indicated using the following categories: (i) to improve or update skills, (ii) within a program of continuous training, (iii) to switch to another job or duties, (iv) to help get started with a first job, (v) within a program of initial training, (vi) for personal interest, and (vii) for unspecified reasons.

As Panel B of Table 2 shows, some $40 \%$ of events are viewed as improving or updating skills. Training to help get started with a first job represents an additional 13.5\% among men and $20.7 \%$ among women, while some $14 \%$ of men and $8 \%$ of women trained to switch to another job. About $20 \%$ of the respondents trained for personal interest or unspecified reasons.

We have regrouped the previous answers into two categories. A first category, called current skills training, includes those activities aimed to update or improve skills in the current job. It includes categories (i), (ii), (iv), and (v), and represents some $70 \%$ of the total training activities. In a second category, called future skills training, we have regrouped those activities aimed to improve skills for a future job or activity. Thought not explicitly stated by the respondent, training for personal interest is likely to develop skills that can be used in the future. Thus, we assume that (vi), together with (iii) and the residual category (vii), represent future skills training.

\section{Training Duration}

The IE reports some information regarding the duration of the training activity. We have used this information to split the training activities into two cateagories: (i) long duration training (one year or more), which comprises vocational formation of tertiary level and specific professional formation with one year or longer duration, and (ii) short duration training (less than one year), which

\footnotetext{
${ }^{9}$ Arulampalam et al. (2003) report that training incidence across some European countries is highest in Britain, Denmark, and Finland, with participation rates above $40 \%$, while Ireland, Italy, and Spain have the lowest rates, of about $7 \%$. Unlike in our data, these rates refer to training activities that took place during the year prior to the survey.
} 
comprises any training with less than one year duration and other forms of training ${ }^{10}$. Panel $\mathrm{C}$ of Table 2 shows that nearly $65 \%$ of the events correspond to short duration training.

\section{Training Content}

Panel D of Table 2 shows the reporting categories for content of training. Training aimed to technicians account for the largest share, of about $37 \%$ for both genders. Women, as compared to men, are more likely to receive formation related to clerk work and teaching. Their relative participation in these fields is, respectively, $23.2 \%$ and $7.7 \%$, which contrasts with the $8.5 \%$ and $3.8 \%$ of men. As opposite, women are less likely to participate in activities related to metallurgy, agriculture, and firm direction, with only $0.6 \%, 1.2 \%$, and $0.9 \%$, respectively, in such activities.

In Panel E of Table 2 we report cross-tabulations of location and purpose for long and short duration training. Training to improve current skills tends to have short duration and, when it has long duration, it tends to be external. Training to switch to another job or for personal interest takes place in the firm seldomly and, as compared to training to improve current skills, tends to have longer duration.

\section{The model}

In order to explain earnings, we use schooling levels, experience, and experience squared as the standard Mincer terms, a set of explanatory variables to capture the observable individual heterogeneity, and a dummy variable for training participation. We suspect that individual and workplace characteristics may affect the market value of training activities. To detect potential differences, we extend the model to include a full set of interaction terms between training and individual's and job characteristics. This allows us to explore how the returns on training vary for workers that differ in professional experience, school qualifications and sector activity. The resulting equation is

$$
\log w=\beta X+\gamma_{1} E D+\gamma_{2} E X P+\gamma_{3} S E+\mu T+\theta_{1} T \times E D+\theta_{2} T \times E X P+\theta_{3} T \times S E+e
$$

where $w$ is the hourly wage, $E D, E X P$, and $S E$ are column vectors of dummies with the education, experience levels and the activity sectors, $T$ is a dummy for training participation, $X$ represents other variables assumed to affect earnings, $\gamma_{i}$ and $\theta_{i}$ are row vectors of coefficients, $\mu$ measures the impact of training on wages, and $e \sim \mathrm{N}\left(0, \sigma^{2}\right)$ is the error term.

Training participants are not necessarily a random group. They may be selected (or self-selected) into training because of unobservable characteristics such as commitment, motivation, flexibility and

\footnotetext{
${ }^{10}$ In Portugal, the duration of any vocational formation of tertiary level is one year or longer. 'Other forms of training" may include informal training such as reading, participation in lectures, courses, seminars, quality circles, and specific company training. Though not stated explicitly, the length of these activities is supposed to be much shorter than a year.
} 
the like. If this is the case, a naive OLS estimation of $\mu$ tends to be biased. To take account of the selectivity problem, we model a participation equation as

$$
T=\beta H+u
$$

where $H$ is a vector of individual and workplace characteristics and $u$ is an error term ${ }^{11}$. Assuming that workers participate in training only if the benefit is positive, we have

$$
\begin{aligned}
& T=1 \text { if } T^{*}>0 \\
& T=0 \text { if } T^{*} \leq 0
\end{aligned}
$$

where $T^{*}$ is the estimated benefit of participation. Therefore, a model that controls for selection bias is

$$
\log w=\beta X+\gamma_{1} E D+\gamma_{2} E X P+\gamma_{3} S E+\mu T+\theta_{1} T \times E D+\theta_{2} T \times E X P+\theta_{3} T \times S E+\lambda \hat{T}^{*}+e
$$

where $\hat{T}^{*}$ is the typical selection correction. We estimate the above model of treatment effects in two ways. When training enters as a single dummy, we adopt a maximum-likelihood method, in which the participation equation (2) and the wage equation (4) are estimated simultaneously. When different types of training are taken into account and therefore training enters as a set of dummies, we adopt a two-step estimator. In a first step we use a multinomial logit to estimate the participation in training events, and calculate a vector $\hat{T}^{*}$ that contains the inverses of the Mill's ratios. Then, in a second stage, we run the OLS wage equation where the inverses of the Mill's ratios have been included as additional explanatory variables. As usual, $\hat{T}^{*}$ is defined as

$$
\hat{T}^{*}=\frac{\phi(\mathrm{z})}{\Phi(\mathrm{z})} \text { if } T=1, \quad \hat{T}^{*}=\frac{-\phi(\mathrm{z})}{1-\Phi(\mathrm{z})} \text { if } T=0
$$

where $\phi$ and $\Phi$ are, respectively, the standard normal density and cumulative functions. In our logit specification, $z$ has to be adjusted to the normal distribution. Thus, $z=\Phi^{-1}(\Lambda(\hat{\beta} H))$, where $\Lambda(\hat{\beta} H)$ is the cumulative logistic distribution ${ }^{12}$. The equation with different types of training is

$$
\log w=\beta X+\gamma_{1} E D+\gamma_{2} E X P+\gamma_{3} S E+\mu T+\theta_{1} T^{\prime} \times E D+\theta_{2} T^{\prime} \times E X P+\theta_{3} T^{\prime} \times S E+\lambda \hat{T}^{*}+e
$$

where $\mu$ and $\lambda$ are row vectors, $T^{\prime}$ is a row vector of dummies for each type of training, and $\hat{T}^{*}$ is a column vector with the inverses of the Mill's ratios.

Ideally, we would like to combine our classification criteria to obtain a large variety of training types, and estimate the full vector of coefficients in a single regression. This approach would allow us

\footnotetext{
${ }^{11}$ See Section 3 for a description of the variables included in $H$.

${ }^{12}$ See Lee (1983) and Maddala (1983) for further details.
} 
to isolate the wage effects of very specific training forms. Although the results of that regression are presented in the paper, it does not constitute our central approach. The reason is small cell size. The number of training events in some of the resulting categories turns out to be rather small. One of our central goals is to explore the difference in the returns to training between workers with different levels of schooling. Since the fraction of the workforce with tertiary education in Portugal is rather small, a model that interacts each type of training with school qualifications can not be estimated. Some of the cells turn out to be empty. Therefore, we have pursued an alternative approach. Rather than presenting the results of a single equation with all the categories of training, we draw on alternative specifications in which training has been classified according to one of the (mutually exclusive) classification criteria described above. Thus, the results should be view as different snapshots of the same reality. As an advantage, this procedure facilitates the comparison between our results and those reported in the existing literature.

\section{Empirical Results}

This section investigates the determinants and wage effects of training. All the regressions are performed for men and women separately. For each gender, two wage regressions are presented. One without interaction terms, one with interaction terms between training and school qualifications, experience, and sector activity.

\subsection{Determinants of training participation}

We regress training participation on a set of socio-economic characteristics. As explanatory variables we include in vector $H$ education, age, private sector or public sector, full-time or part-time contract, tenure, firm size, whether the worker holds a second activity, whether the worker has always resided in Portugal, a set of 16 dummies for the economic sectors, and 7 dummies for the Portuguese regions.

Table 3 presents the logit estimates on training participation. The estimated coefficients are the odds ratios. For the reference worker, they represent the factor by which the probability of selection into training increases for a marginal increase in a continuous variable and for a discrete change in the probability for dummy variables ${ }^{13}$.

An important finding is that training goes mainly to more educated individuals. Higher educational levels are associated to higher training participation. In particular, workers with some education qualifications are between 3 and 4 times more likely to participate in training than workers with less than primary education.

\footnotetext{
${ }^{13}$ The reference individual is a worker with less than primary education, aged less than 30 years, who does not work in a second activity, has always resided in Portugal, is working full-time in the private sector, in a firm with more than 500 workers, in the commerce sector, and in the North region of Portugal.
} 
As a second finding, older individuals tend to receive less training. The likelihood of training participation is about one third lower for workers aged between 30 and 44 years, and about one half lower among workers aged above 44 years. The negative association between age and training participation is in line with the human capital theory that predicts that younger workers are more likely to train than older workers, since the period over which their investment can be amortized is longer. This result contradicts the concept of lifelong learning, which suggests that, in order to prevent that skills become obsolete, continuing training is observed across all age groups.

The impact of the remaining variables is as follows. Having a second activity is associated to higher training participation. This may be due to the fact that individuals holding a second activity are more motivated or committed to their profession and, accordingly, they are more likely to make an effort to develop competencies on the job and improve performance. The probability of training varies significantly with tenure in the job, and in a non-linear way. Workers in average-sized firms, and women in culture, sports, leisure, public administration, insurance and finance are more prone to get training. As opposite, men in the construction, food, drinks, and tobacco sectors are less likely to get trained. Neither having a full-time contract nor working in the public sector appear to be significant at the $5 \%$ confidence level.

The evidence presented so far is similar to that reported in Arulampalam et al. (2003) and OECD (1999) for European countries. There are, however, two differences. In most European countries, the incidence of training is higher among women and public servants. As opposite, men in Portugal participate in training as much as women. Moreover, the effect of working in the public sector is small, as it is solely significant among men at the $10 \%$ level. This may indicate that public firms may offer little advantages to training participation to their employees who, on the other hand, might have little incentives to enrol into such activities. This is unfortunate, insofar as Portuguese employers in the private sector offer already little support to training activities as compared to other European countries ${ }^{14}$.

Tables 4 and 5 focus on the selection into different types of training. For each alternative classification, we present the results of multinomial logits where the dependent variable is a 3-point categorical variable indicating the worker's allocation to training events, where the reference category is no training. The estimated coefficients are relative risk ratios (RRR), which can be interpreted as odds ratios. Rather than focussing on categories of explanatory variables, in the following we comment the main differences between training types.

We start by differentiating between internal and external training. As a main contrast, age has a very limited influence on the probability of participating in internal training, while it has a large (and negative) impact on the likelihood of external training. Having a second activity has a significant effect on external training. As opposite, it accounts poorly for men's internal training. As an

\footnotetext{
${ }^{14}$ According to OECD (1999), Portuguese private sector employers rank last among European countries in financing training activities for their employees.
} 
additional effect, women who have always been Portuguese residents tend to participate less in internal training. Differentiating between training for future skills and training to improve current skills reveals that age exerts a more negative impact on the former than in the later, while the role of education is similar in both categories. When duration of training is considered, we find that having secondary or higher education promotes participation in either type of training, though the impact is much greater in the case of long duration training. The negative effect of age is larger among women than among men when it comes to long duration training, while the opposite occurs with short duration training.

Looking at the average probability of participation, one finds that women tend to enrol into external training more than men. Whether this fact can be attributed to a labour market signal is a question we answer in section 3.5.

The estimation of a multinomial logit model assumes that the exclusion of one of the outcomes in the dependent variable does not affect the relative risk ratios of the regressors in the remaining categories. This assumption is known as the independence from irrelevant alternatives (IIA) and, if it does not hold, the parameter estimates may be inconsistent. In a first step, individuals might be selected (or self-selected) into training and, in a second step, decide whether they choose training type A or training type B. In this case, the IIA assumption is unlikely to hold, since ending up in training category A is not independent from being in category B. We have used the Hausman test to check whether or not the IIA assumption holds. The chi-squared statistics of Table 6 show that for all training classifications and for both genders the null hypothesis is not rejected, i.e., there is no evidence that the IIA assumption has been violated.

\subsection{The problem of selection into training}

Individuals who receive training may be not a random sample, but selected (or self-selected) because of some unobservable characteristics, such as a higher degree of productivity or commitment. Employers may offer training schemes only to those workers whose expected productivity is higher and, at the same time, more motivated individuals might be more likely to enrol into courses, seminars, lectures and so on. Therefore, the profitability of the training activity might be related to the probability of participation, thus giving rise to the common problem of selection bias.

To control for the potential endogeneity of training, we draw on a treatment effects model. As long as the errors of the participation equation are uncorrelated with the errors of the wage equation, the estimated coefficients are no longer exposed to selectivity bias ${ }^{15}$. This approach requires that some variables in the selection equation -which are supposed to affect training but not wages- are omitted from the wage equation. We use as excluded instruments two dummy variables: having a second activity and always resident in Portugal. The motivation is as follows. Holding a second activity may

\footnotetext{
${ }^{15}$ However, there is no guarantee that just by addressing the endogeneity of training our estimates will be less biased if other forms of self-selection are present.
} 
proxy the individual's degree of commitment and motivation. If more motivated individuals are more likely to enrol into training activities, then such variable should account for training participation. At the same time, individuals who have lived in other countries may be more flexible and ready to upgrade their skills. Moreover, once abroad, they may have benefited from greater facilities in the access to training. In order to capture this effect, we use a dummy that is activated if the worker has always resided in Portugal.

The excluded instruments account reasonably well for training participation. In Table 3, having $a$ second activity is highly significant among men and women. As Tables 4 and 5 show, the significance of this variable holds for all types of training and both genders, save the case of internal training among men. As opposite, Portuguese residence is significant only in some cases, and helps only partially to identify workers with training events.

In Appendix B, we perform several well-known tests to asses the quality of the excluded instruments. We find that our exclusion restrictions pass the Sargan's orthogonality test and the Bound et. al. (1995) validity test ${ }^{16}$. We also investigate the effects of adding two additional exclusion restrictions: looking for a second activity and marital status (single or not). We found that these two variables were significant to account for some training events. However, the orthogonality test rejects their inclusion in the participation equation. Interestingly, the sensitivity analysis reported in Appendix B shows that our estimates are reasonably accurate and robust to changes in the participation equation.

\subsection{Returns to training}

Our wage equations control for school highest qualification, experience (and squared), tenure, public or private sector, full-time or part-time job, and workplace size. In addition, regional and sectoral labour market conditions are captured by 7 dummies for Portuguese regions, and 16 dummies for economic sectors. Standard errors are corrected for heterocedasticity. As usual, all the comparisons will be made, henceforth, ceteris paribus and with respect to the reference individual ${ }^{17}$.

It should be stressed that throughout the paper we do not control for female self-selection into the labour market. This might yield biased estimates as long as women that currently work are not a random group. However, evidence suggests that this is not the case. For instance, Pereira and Martins $(2001,2002)$ have used standard instruments to account for female participation in the labour market. The selection term in their wage equation is not significant, thus indicating that the OLS and the 2-

\footnotetext{
${ }^{16}$ It could be argued that 'having a second activity' is likely to be correlated with wages. This would be the case if (i) the wage variable includes wages from a second activity, and (ii) individuals with lower wages tend to look for a second activity in order to raise monthly earnings. As regards (i), our wage variable refers to the main working activity and, therefore, does not include earnings from a second activity. We also checked hypothesis (ii), and found in calculations not reported here that 'having a second activity' is not significant in the wage regression.

${ }^{17}$ The reference individual is an untrained worker with less than primary education, less than 6 years of tenure, working full-time in the private sector, in a firm with more than 500 workers, in a commerce occupation, and in the North region of Portugal.
} 
step estimates are statistically equivalent. In this paper, we will assume that working women are a representative sample.

Table 7 reports the OLS and the treatment effects estimates jointly. We find that training has a large and significant impact on wages. However, the estimated effect depends importantly on the econometric specification. Under OLS, the estimated return for an employee with reference characteristics is $11.9 \%$ among men and $8.2 \%$ among women ${ }^{18}$. Under the treatment effects model, the return for an employee with reference characteristics is $21.8 \%$ among men and $36.5 \%$ among women.

According to the selection term, trained men appear to be a random group. In this case, the use of an OLS procedure is justified and, thus, the OLS model is our preferred specification among men. As opposite, the selection term is highly significant for women, which suggests that trained women are not a random group. Thus, we draw on the treatment effects model rather than on OLS estimation for the female sub-sample.

As regards the remaining variables, we find that having primary, secondary and tertiary education raises wages by about $19 \%, 33 \%$ and $88 \%$, respectively. The estimated returns are practically identical for men and women. As expected, hourly wages are higher among employees with more experience and tenure. Working part-time, in a relative large firm, and in the public sector is associated to additional wage increases. The construction, transports, education, insurance and finance sectors pay higher wages, while the retail and food sectors pay lower wages.

\subsubsection{Differences between groups of workers}

Table 8 presents a more elaborate model where the training dummy interacts with education levels, professional experience, and sector activities. Now, the reference individual has lowest education attainment and longest professional experience. As a main result, we find that gains from training are largest for less educated and high experienced workers.

Among men, the selection term is only significant at the $10 \%$ confidence level. In this case, it is not clear whether rely on the treatment effect or the OLS model. According to the former, tertiary educated workers receive significantly lower returns to training. According to the later, differences between education groups are not significant. This mixed evidence may seem contradicting. However, it should not be so if we consider that differences across education groups might depend on the type of the training. Indeed, the low significance of the OLS interaction terms is due to compensating effects. As we show below, once we differentiate between training types, we find that returns on most

\footnotetext{
${ }^{18}$ Our OLS coefficients are in line with those reported in Hartog et al. (2000). They find that in a model with a full set of control variables the OLS returns to training are $11.4 \%$ for men and $6.7 \%$ for women. Saraiva (1999) reports a somewhat smaller premium, of about 7\% in the OLS specification. The difference with Saraiva's work can be attributed to differences in the sample selection and the wage variable. Saraiva excludes from his analysis workers in the regions of Madeira and Açores. We found, in calculations not reported here, that returns to training in Madeira and Açores are higher that in the rest of the country. As for the wage variable, Saraiva uses interval-coded wages. As a consequence, his results are exposed to the problem of top-coding.
} 
training types are decreasing in education, regardless of the econometric approach. As for female workers, it is convenient to focus on the model of treatment effects. We find that women with tertiary and secondary education earn some 22 and 11 percentage points less, respectively, than those with less than primary education.

The interaction terms additionally show that experience gives a significant yield. We detect that, among men, returns to training can be as high as $17.8 \%$ for high experienced workers and almost null for low experienced workers. Similarly, women with less than 25 years of experience earn, according to the treatment effects model, between 13.3 and 8.6 percentage points less than the reference group. The role of experience may indicate that training helps update the skills of workers whose formal qualifications are more obsolete. As a consequence, more experienced employees end up receiving larger wage benefits. Another candidate explanation is that more experienced workers have more bargaining power than job entrants and therefore can capture a larger premium on their training activities.

As Table 8 shows, the sector activity is an additional determinant of the market value of training. Workers in restaurants, men in education, and women in construction activities earn relatively less. To our eyes, sector differences seem to indicate that beyond individual and job characteristics, occupations and sectoral conditions are an important determinant of the earning gains arising from training activities.

To sum up, we find large and significant returns to training for all categories of workers. Notwithstanding this, there are substantial differences between workers with different gender, experience, education background, and sector activity. The negative sign of the selection term indicates that, among women, earnings gains from training tend to be greater for those who are less likely to get trained.

\subsubsection{Do acquired skills become obsolete?}

The results presented so far assume that the wage increase associated to training does not depend on the years that have elapsed since the training activity was finished. This may be a strong assumption. An important issue in the literature is to test whether and to what extent the returns to training diminish over time. As acquired skills become obsolete, the earnings gains arising from past training may disappear.

Despite its cross-section nature, our data allows us to explore the wage impact of training at different time horizons. Individuals in our sample report the date at which they finished training. Using this information, we splitted trained workers into three groups. $45.2 \%$ of the workers completed training during the 5 years prior to the survey, $36.8 \%$ between 6 and 15 years prior to the survey, and $18.1 \%$ more than 15 years before the survey. Then, we constructed a set of dummies to differentiate between these categories of trained people. To save space, we do not report the results here. We found 
that the interaction terms were poorly defined for men and, thus, no significant differences in the returns to past and recent activities could be established.

Somewhat striking, we found that women trained more than 15 years ago receive larger wage gains than women trained more recently. The estimated differential was 27.1 and 5.8 percentage points for women who finished their training activity more than 15 years ago and between 6 and 15 years ago, respectively. This finding seems to provide further evidence against the concept of lifelong learning, which is based on the idea that skills become obsolete relatively fast. Moreover, it suggests that women may have strong incentives to enroll into training activities. The time horizon along which they can amortize their investment seems to be longer than previously thought.

\subsection{Training in the private sector and in the public sector}

In this section, we ask whether and to what extent the wage effects of training in the public and the private sector are different. To that purpose, we split the sample into private and public servants, and re-calculate the returns to training for both sub-samples. In Tables 9 and 10 we report the estimates with interaction terms. Women trained are not a random sample in either sector. As opposite, men trained appear to be a random sample, irrespective of the sector. Thus, we take OLS for men and the treatment effects model for women as the appropriate specifications.

Several things are worth noting. First, returns to training are very similar in both sectors. Focussing on gender differences, we find that earnings gains due to training are higher among women than among men in both sectors. Women earn more than a $60 \%$ premium in either sector. As opposite, the premium for men is some $17 \%$ in the private sector and $16 \%$ in the public sector. It should be noted that, among men, controlling for the endogeneity of training gives estimates that are about 10 percentage points higher. However, we disregard these estimates, for the selection term is nonsignificant.

Second, in the public sector the premium on training is similar across experience groups. As opposite, in the private sector employees with short professional experience gain significantly less from training than employees with long professional experience. Thus, for example, the premium is even negative for private sector men with less than 6 years of experience, according to the OLS estimation. Among women in the private sector, job entrants receive some 26 percentage points less than those with long professional experience.

Third, the returns to training across education groups are quite homogeneous in the private sector, while in the public sector there is significant variation with qualifications. Among women in the public sector, those with tertiary, secondary, and primary education receive a premium on training that is, respectively, 38.8, 29.1, and 18.9 percentage points below the premium earned by women with the lowest school attainment. Among men, those with tertiary education earn some 15 percentage points less relative to the less skilled. This evidence may indicate that for high professional categories, wages in the public sector are rather insentitive to additional investments in human capital. 
To sum up, we can obtain important information by differentiating between the public sector and the private sector. On the one hand, education appears to be a key determinant of the returns to training in the public sector. On the other hand, experience governs the returns to training in the private sector. On average, though, returns to training are very similar in both sectors.

\subsection{The returns to different types of training}

Our data allows us to explore what forms of training have a larger impact on wages. In order to carry such analysis, we use a variety of specifications where training has been classified according to alternative criteria.

As Table 11 shows, most forms of training have wage enhancing effects. Training internally and to improve current skills gives largest gains. As opposite, training to switch to another job or for personal interest (future skills) gives lowest gains.

Somewhat surprisingly, Panel $\mathrm{C}$ indicates that short duration training raises wages more than long duration training. Our estimates seem to contradict the intuition that investing in human capital for longer periods must yield larger gains. It turns out, however, that more than $35 \%$ of the training with duration less than a year is internal an aimed to improve current skills, while this proportion falls to nearly $14 \%$ for training with duration longer than a year. Thus, the coefficient on short duration training reported in Panel $\mathrm{C}$ might be capturing the (positive) effects of internal and current skills training. To test this hypothesis, we present in Panel D a model with a larger set of training dummies. The coefficients correspond to the eight types of training arising from our classification criteria (location, purpose, and duration). We find that short duration training is associated to larger gains than long duration training only when it is internal and aimed to update current skills. In such cases, the benefits of short training spells, with specific contents, and aimed to update or improve skills needed at the current job are substantial. In other cases, the returns to long training programmes can be higher than the returns to short programmes. Thus, for example, the wage gains earned by women enrolled in long duration, external, future skills training are remarkable. This suggests that the acquisition of new skills off-the-firm might generate positive spillovers at the current job, thus increasing wages, even though the acquired skills are not directly related to those needed at the workplace. In the previous section we found that, as compared to men, women are more prone to train externally and for longer periods. Our estimates suggest that this feature may obey to a labour market signal, insofar as women obtain considerable gains from training with such characteristics.

Table 12 reports the OLS estimates when training is classified according to its content. Due to small cell size, we do not pursue this extension with a treatment effects model. The reported coefficients indicate that those training schemes aimed to firm directors, workers of the health and life sciences, clerks and secretaries, and technicians are associated to larger wage increases. On the contrary, programmes aimed to agricultural workers, fishermen and employees in the civil construction are not associated to sizeable wage increases. 
Tables 13-16 are devoted to the specifications with interaction terms. The results suggest that for most training types the returns are significantly lower among more educated individuals. For most training categories, trained workers are not a random sample. We find that, among men, internal, current skills and short duration training carry a lower premium for individuals with higher schooling levels. As Table 14 shows, the estimated coefficients are between 26 and 37 percentage points lower among tertiary educated workers, and between 14 and 21 percentage points lower among secondary educated workers. As for women, those with higher education receive smaller wage gains from all types of training. Table 16 indicates that, as compared to the base category, the differential ranges from some 27 percentage points in the case of internal training to 46 percentage points in the case of long duration training. As regards experience, we find that returns to external training are particularly sensitive to the worker's professional experience.

\subsection{Transitions between employment and unemployment}

One non-pecuniary benefit of training is security of employment. The IE asks individuals about their laboral situation one year prior to the interview. Using this information, we construct transition matrices from employment to unemployment and vice versa, and ask to what extent training affects the transition probabilities.

To carry such analysis, we restrict our sample along two dimensions. First, we drop individuals that at some point report not being employed or unemployed. Second, we consider only male workers, since they constitute the lion part of the Portuguese workforce ${ }^{19}$. In the resulting sub-sample, 1,237 respondents were unemployed one year prior to the survey. $570(46.1 \%)$ had obtained a job by the time of the survey. On the other hand, 17,847 were employed one year prior to the survey. One year after, $468(2.6 \%)$ were unemployed. We model entry and exit of unemployment as a function of gender, education, training and experience. Both equations include an additional set of regional dummies.

The results reported in Table 17 are somewhat upsetting. Few effects turn out to be significant. As regards exit from unemployment, the education variables and training participation appear to be irrelevant. As opposite, the effect of professional experience is negative and significant. As regards entry into unemployment, our estimates suggest that workers with tertiary education are more likely to avoid unemployment. Being trained does not reduce significantly the probability of being unemployed, which is in line with the evidence reported in Ok and Tergeist (2003) for European countries. Our finding should be interpreted cautiously, though. The pseudo R-squared is only 0.0193 , and only one of the explanatory variable is significant at the 5\% confidence level. Thus, we suspect

\footnotetext{
${ }^{19}$ It is convenient to leave female workers out from the analysis. There is evidence that women doing homework tend to report unemployment. This bias would lead us to obtain misleading results. Moreover, variables other than education, experience, and training are likely to play an important role in the female transition probabilities. Thus, for example, the employment status of female workers may be very sensitive to the household composition. Unfortunately, our data set reports little on household's characteristics, and such variables can not be included in the transition equations.
} 
that the transition equation is poorly specified and that richer specifications are needed to assess the real impact of training activities on the transition probabilities.

\section{Conclusion}

In this paper we have explored the extent, determinants and wage effects of training in Portugal. In a first stage, we showed that there are considerable differences in training participation across groups, with elder, low educated workers participating substantially less in training activities. In a second stage, we explored the impact of training on wages. Our main findings can be summarized as follows. Returns to training activities are large and significant. Discriminating between education levels, experience, gender, the public and the private sector, and activity sectors reveals important differences across categories of workers. Workers with low qualifications and long professional experience earn larger returns. Women receive larger returns than men, though they are subject to greater variation across education and experience groups. The average effect of training is similar in the private sector and in the public sector. Experience in the private sector and education in the public sector are key determinants of the returns to training. We differentiated between different types of training. We found that some activities are more profitable than others. Training to improve current skills and training in the firm give largest returns. Further, programs aimed to firm directors, workers of the health and life sciences, clerks and secretaries, and technicians are associated to additional wage increases. As regards employability, we find that trained workers are as likely to find (maintain) a job as untrained workers.

As a shortcoming, our paper considers only participation in training activities. It does not take into account the amount, intensity, quality, and costs of such activities. Such information would be valuable to shed light on important questions, such as the net returns on human capital investment that employers and employees earn, the complementarities between different training schemes, and whether training programs that lead to qualifications have larger impact on wages. Further, we use cross-sectional data. Longitudinal data containing the timing of the investment in which earnings growth is the focus of the analysis is preferable, insofar as the temporal ordering of cause and effect can be established. Unfortunately, in the Portuguese Labour Force Survey individuals are kept for a maximum of 6 quarters, which is a very small period to assess the impact of training events on earnings. Further progress in the acquisition and development of new training data in Portugal could help fill these gaps ${ }^{20}$.

Nonetheless, we can draw some tentative conclusions with the limited data currently available. First, the incidence of training in Portugal is one of the lowest in Europe, while the estimated returns

\footnotetext{
${ }^{20}$ A candidate longitudinal data source is the Portuguese sub-sample of the European Community Household Panel. However, it presents additional problems, such as gaps in the training data and small estimating subsamples due to the low incidence of training and the high concentration (almost 80\%) of workers in the first education level.
} 
to training activities appear to be considerable. Therefore, policies aimed to encourage and increase the overall participation in training may be of particular importance ${ }^{21}$. Second, it has been argued that the different returns observed across different types of workers are due to barriers to the access to training. The argument is that workers and employers would increase training participation across categories of workers until their marginal productivity equalize. According to this, we find that the barriers in Portugal are important, with low qualified workers typically participating less in training activities. In this scenario, low training participation raises equity concerns. The returns to formal education in Portugal are highest among European countries, and the wage gap between high and low skilled workers is substantial. Thus, if training increases wages and is concentrated towards more educated individuals, lower training participation among specific groups of workers may deteriorate the labour market position of already disadvantaged individuals. Further, we find that returns to training are higher among low educated workers. In the international literature, there is no general consensus concerning the returns that workers with different educational background receive from training ${ }^{22}$. The evidence for Portugal suggests that training is remedial, and that policies aimed to facilitate the access to training of the less skilled may contribute to reduce wage inequality. ESF assistance can contribute importantly to implement such policies. Unfortunately, according to the monitoring committees of ESF programmes, execution rates are being rather low in Portugal. Our findings suggest that an important opportunity to improve the labour market position of less favored individuals is, therefore, being lost.

Recently, the OECD has recommended that reforms in the Portuguese Labor Market should be accompanied by a stronger emphasis on training ${ }^{23}$. This paper provides useful information regarding those types of training and groups of workers towards which those reforms should be oriented.

\section{References}

Arulampalam, W., A. Booth and M. Bryan (2003), Training in Europe. IZA Working Paper 933.

\footnotetext{
${ }^{21}$ For a comprehensive analysis of failures in the labour, capital and training markets that can lead to underinvestment in training and a discussion on different policy instruments aimed to increase training participation, see OECD (2003a) and Ok and Tergeist (2003).

${ }^{22}$ Among others, Lynch (1992) for US, Blundell et al. (1996) for UK, and Kuckulenz and Zwick (2003) for Germany find that returns are higher for more educated workers, while Long (2001) for Australia and OECD (1999) for a variety of countries suggest the opposite.

${ }^{23}$ According to OECD (2003b), reforms in the Portuguese Labor Market "should be accompanied by a stronger emphasis on vocational training, to ease the school-to-work transition. New rules permitting employment of unqualified youths on condition that training is provided by the employer may help, but it would be better if the schools themselves were better able to provide school-leavers with qualifications useful to employers [...]. These reforms should be accompanied by the training and re-training of existing workers. The government's aim to provide employment-related training to all youths that are registered in employment centers and a renewed emphasis on life-long training are welcome. If successful, these incentives would increase the productivity and earnings capacity of those who might otherwise exit the labour force".
} 
Asplund, R. (2004), The Provision and Effects of Company Training - A brief review of the literature. ETLA Working Paper 907.

Blundell, R., L. Dearden and C. Meghir (1996), The determinants and Effects of Work-related Training in Britain. The institute of Fiscal Studies, London.

Bound, J., D. Jaeger and R. Baker (1995), Problems with Instrumental Variables Estimation when the Correlation Between the Instruments and the Endogenous Explanatory Variable is Weak. Journal of the American Economic Association, vol. 90, 430.

Brunello, G. (2001), On the complementarity between Education and Training in Europe. IZA Woking Paper 309.

Booth, A., M. Bryan (2002), Who pays for General Training? New Evidence for British Men and Women. IZA Working Paper 486.

Bound, J., D. Jaeger and M. Baker (1995), Problems with Instrumental Variables Estimation when the Correlation between the Instruments and the Endogenous Explanatory Variables is Weak. Journal of the American Statistical Association, June, 90, 430.

CGQCA (Comissão de Gestão do Quadro Comunitário de Apoio III) (2004), Quadro Comunitário de Apoio III - Portugal 2000-2006. Relatório Final (Community Support Framework III - Portugal 2000-2006. Final report). Available at http://www.qca.pt/publicacoes/RelatQCA2003.pdf

Dearden, L., H. Reed and J. Van Reenen (2000), Who gains when workers train?. The Institute for Fiscal Studies WP 00/04.

EUSROSTAT (2004), EUROSTAT structural indicators, Luxembourg. Available at: http://europa.eu.int/comm/eurostat/

Hartog, J., P.T. Pereira and J.C. Vieira (2000), Vocational Training and Earnings in Portugal. Economia, vol. XXIV, January-October 2000.

Heckman, J. (1999), Policies to Foster Human Capital. NBER Working Paper 7288.

Klepinger, D., S. Lundberg and R. Plotnik (1995), Instrument Selection: The Case of Teenage Chilbearing and Women's Educational Attainment. Institute of Research on Poverty Discussion Paper 1077.

Kuckulenz, A. and T. Zwick (2003), The Impact of Training on Earnings - Differences between Participant Groups and Training Forms. ZEW Discussion Paper 03 - 57.

Lee, L.F. (1983), Generalized Econometric Models with Selectivity. Econometrica, 51(2), 507512. 
Long, M. (2001), The Effect of Firm-Based Training on Earnings. Monash University Working Paper 37.

Lynch, L. (1992), Private Sector Training and the Earnings of Young Workers. American Economic Review 82, 299-312.

Lynch, L.M. and S.E. Black (1998), Beyond the Incidence of Employer-Provided Training. Industrial and Labour Relations Review 52, 1, 64-81.

Maddala, G.S. (1983), Limited-dependent and Qualitative Variables in Econometrics. Cambridge: Cambridge University Press.

OECD (1999), Training of Adult Workers in OECD Countries: Measurement and analysis. OECD Economic Outlook 1999, OECD, Paris.

OECD (2003a), Employment Outlook. Paris.

OECD (2003b), Portugal - Assessment and Recommendations, OECD Economic Surveys, available at http://www.bportugal.pt/publish/other/ocde03e.htm.

Ok, W. and P. Tergeist (2003), Improving Workers' Skills: Analytical Evidence and the Role of the Social Partners. OECD Social, Employment and Migration Working Papers 10, Paris.

Pereira, P.T. and P.S. Martins (2002), Is there a Return-Risk Link in Education? Economic Letters 75, 31-37.

Pereira, P., and P.S Martins, (2001), Education and Earnings in Europe - A Cross Country Analysis of Returns to Education, in C. Harmon, I. Walker and N. W. Nielsen (eds.).

Pereira, P.T. and P.S. Martins (2002), Education and Earnings in Portugal. Bank of Portugal Conference Proceedings 2002.

Pischke, J. (2001), Continuous Training in Germany. Journal of Population Economics 14, 523548.

Saraiva, A. (1999), Incidência e Impacto Salarial da Formação Profissional em Portugal (Extent and Wage Impact of Training in Portugal). Economia vol. XXII, January- May 1999.

Van de Werfhorst, H. and M. Gangl (2002), The From-School-to-Work-Dynamics. Manuscript.

Verhofstadt, E., T. Schatteman, E. Omey, and P. Coppieters (2002), A Dynamic Look at the Transition to the Labor Market. Manuscript.

Vieira, J. (1999), Returns to Education in Portugal, Labour Economics 6, 535-541. 
White, H. (1980), A Heteroskedasticity-consistent covariance matrix estimator and a direct test for heteroskedasticity. Econometrica 48, 817-838.

Zwick, T. (2002), Continuous Training and Firm Productivity in Germanny. ZEW Discussion Paper 02-50. 
Table 1: Means of selected variables

\begin{tabular}{|c|c|c|}
\hline Variables & Total & $\begin{array}{l}\text { \% Training } \\
\text { Participants }\end{array}$ \\
\hline Log hourly wage & 1.06 & 1.30 \\
\hline Log Hours & 3.67 & 3.67 \\
\hline Experience & 18.7 & 16.4 \\
\hline \multicolumn{3}{|c|}{ Proportions (\%) } \\
\hline Female & 45.6 & 8.7 \\
\hline Single & 26.9 & 8.8 \\
\hline Partime & 3.4 & 5.7 \\
\hline Public & 21.4 & 13.2 \\
\hline \multicolumn{3}{|l|}{ Cohort } \\
\hline Age $<30$ years & 35.1 & 9.3 \\
\hline 30 years $\leq$ age $<45$ years & 41.2 & 9.0 \\
\hline Age $\geq 45$ years & 23.7 & 6.8 \\
\hline \multicolumn{3}{|l|}{ Tenure } \\
\hline tenure $<6$ years & 47.9 & 8.5 \\
\hline 6 years $\leq$ tenure $<26$ years & 44.6 & 8.8 \\
\hline tenure $\geq 26$ years & 7.5 & 7.4 \\
\hline \multicolumn{3}{|l|}{ Firm Size } \\
\hline firmsize $<20$ employees & 26.7 & 8.8 \\
\hline $20 \leq$ firmsize $<500$ employees & 11.4 & 15.1 \\
\hline firmsize $\geq 500$ & 61.9 & 7.2 \\
\hline \multicolumn{3}{|l|}{ Education } \\
\hline Less than 4 years & 4.3 & -- \\
\hline 4 years & 32.1 & 2.6 \\
\hline $6-9$ years & 40.6 & 9.7 \\
\hline Secondary & 13.0 & 20.0 \\
\hline Tertiary & 9.9 & 12.2 \\
\hline \multicolumn{3}{|l|}{ Sector } \\
\hline $\begin{array}{l}\text { S1. Agriculture, fishing } \\
\text { and extraction }\end{array}$ & 3.4 & 3.9 \\
\hline S2. Food, drinks and tobacco & 3.1 & 5.7 \\
\hline S3. Retail & 10.8 & 4.6 \\
\hline S4. Wood and paper & 3.4 & 6.5 \\
\hline $\begin{array}{l}\text { S5. Chemical and mineral } \\
\text { products }\end{array}$ & 3.5 & 7.8 \\
\hline $\begin{array}{l}\text { S6. Metallurgy, equipment } \\
\text { and vehicles }\end{array}$ & 8.5 & 7.8 \\
\hline S7. Construction & 11.6 & 3.4 \\
\hline S8. Commerce & 12.1 & 8.5 \\
\hline S9. Restaurants & 4.8 & 8.2 \\
\hline $\begin{array}{l}\text { S10. Transports \& } \\
\text { Telecommunications }\end{array}$ & 4.4 & 10.0 \\
\hline $\begin{array}{l}\text { S11. Insurance and financial } \\
\text { Intermediation }\end{array}$ & 2.3 & 16.4 \\
\hline S12. Public administration & 8.6 & 14.4 \\
\hline S13. Education & 7.5 & 10.0 \\
\hline S14. Health & 6.7 & 11.8 \\
\hline S15. Culture, sport, leisure & 2.7 & 15.8 \\
\hline S16. Others & 6.7 & 9.2 \\
\hline Share & 100 & 8.4 \\
\hline
\end{tabular}


Table 2: Training incidence by categories (\%)

\begin{tabular}{|c|c|c|c|c|}
\hline & & & \multicolumn{2}{|c|}{ Gender } \\
\hline & & & Men & Women \\
\hline \multicolumn{5}{|c|}{ A. Training Location } \\
\hline \multicolumn{3}{|c|}{ College and university } & 3.2 & 4.5 \\
\hline \multicolumn{3}{|l|}{ Firm } & 31.8 & 22.4 \\
\hline \multicolumn{3}{|c|}{ Professional school } & 21.0 & 23.1 \\
\hline \multicolumn{3}{|c|}{ Center of professional formation } & 18.4 & 21.2 \\
\hline \multicolumn{3}{|l|}{ Others } & 25.6 & 28.8 \\
\hline \multicolumn{5}{|c|}{ B. Training Purpose } \\
\hline \multicolumn{3}{|c|}{ To help get started with a first job } & 13.5 & 20.7 \\
\hline \multicolumn{3}{|c|}{ To improve or update skills } & 42.5 & 40.9 \\
\hline \multicolumn{3}{|c|}{ To switch to another job or duties } & 14.0 & 8.4 \\
\hline \multicolumn{3}{|c|}{$\begin{array}{l}\text { Within a program of promotion of employment: } \\
\text { initial training }\end{array}$} & 2.6 & 5.5 \\
\hline \multicolumn{3}{|c|}{$\begin{array}{l}\text { Within a program of promotion of employment: } \\
\text { continuous training }\end{array}$} & 6.5 & 6.0 \\
\hline \multicolumn{3}{|c|}{ For personal interest } & 14.5 & 14.4 \\
\hline \multicolumn{3}{|l|}{ Others } & 6.6 & 4.1 \\
\hline \multicolumn{5}{|c|}{ C. Training Duration } \\
\hline \multicolumn{3}{|c|}{ Vocational formation of tertiary level } & 4.4 & 4.8 \\
\hline \multicolumn{3}{|c|}{$\begin{array}{l}\text { Specific professional formation with one year or longer } \\
\text { duration }\end{array}$} & 31.5 & 31.0 \\
\hline \multicolumn{3}{|c|}{ Any training with less than one year duration } & 40.4 & 41.3 \\
\hline \multicolumn{3}{|l|}{ Others } & 23.6 & 23.0 \\
\hline \multicolumn{5}{|c|}{ D. Training Content } \\
\hline \multicolumn{3}{|c|}{ Health and life sciences } & 3.0 & 4.7 \\
\hline \multicolumn{3}{|c|}{ Teachers and related professions } & 3.8 & 7.7 \\
\hline \multicolumn{3}{|c|}{ Technicians of physics and related fields } & 13.5 & 20.9 \\
\hline \multicolumn{3}{|c|}{ Technicians of other areas } & 23.2 & 17.0 \\
\hline \multicolumn{3}{|l|}{ Firm directors } & 1.7 & 0.9 \\
\hline Clerks and sec & Iries & & 8.5 & 23.2 \\
\hline Personal servi & & & 9.3 & 11.2 \\
\hline Agricultural n & ers and fisherm & & 2.8 & 1.2 \\
\hline Workers of $\mathrm{m}$ & urgy & & 18.4 & 0.6 \\
\hline Workers of gr & ic arts, civil cor & & 9.4 & 6.7 \\
\hline Others & & & 6.5 & 6.0 \\
\hline & E. Detaile & n of training & & \\
\hline & Current skills & & 4.3 & 5.3 \\
\hline Long duration & & External & 16.8 & 17.7 \\
\hline & & Internal & 1.1 & 1.5 \\
\hline & Future skills & External & 9.6 & 11.0 \\
\hline & & Internal & 22.5 & 18.0 \\
\hline & Current skills & External & 28.0 & 27.9 \\
\hline shon uuration & & Internal & 2.8 & 2.6 \\
\hline & & External & 14.1 & 16.0 \\
\hline
\end{tabular}


Table 3: Selection into training - Training included as a dummy

\begin{tabular}{|c|c|c|c|c|}
\hline & \multicolumn{2}{|c|}{ Men } & \multicolumn{2}{|c|}{ Women } \\
\hline & Odd ratio & z-ratio & Odd ratio & z-ratio \\
\hline Primary & $3.099 * * *$ & 9.46 & $3.481 * * *$ & 8.04 \\
\hline Secondary or higher & $4.028 * * *$ & 11.52 & $3.757 * * *$ & 8.94 \\
\hline 30 years $\leq$ age $<45$ years & $.7187 * * *$ & -2.42 & $.6419 * * *$ & -2.92 \\
\hline age $\geq 45$ years & $.4671 * * *$ & -4.34 & $.5613^{* * *}$ & -2.90 \\
\hline Public sector & $1.347 *$ & 1.81 & 1.130 & 0.70 \\
\hline Partime & 1.302 & 0.68 & .8377 & -0.65 \\
\hline Tenure & $1.139 * * *$ & 7.33 & $1.131 * * *$ & 5.56 \\
\hline Tenure squared & $.9975 * * *$ & -4.65 & $.9972 * * *$ & -3.90 \\
\hline firmsize $<20$ employees & 1.190 & 1.50 & 1.096 & 0.79 \\
\hline $20 \leq$ firmsize $<500$ employees & $2.778 * * *$ & 8.38 & $2.510^{* * *}$ & 7.05 \\
\hline Second activity & $1.548 * * *$ & 3.10 & $2.210^{* * *}$ & 3.96 \\
\hline Always resident & .8374 & -1.30 & .8897 & -0.83 \\
\hline Food, drinks and tobacco & $.4780 * *$ & -2.08 & .5154 & -1.57 \\
\hline Retail & .9733 & -0.10 & $.6070 *$ & -1.89 \\
\hline Wood and paper & .6763 & -1.46 & 1.242 & 0.59 \\
\hline Chemical products & .9105 & -0.38 & .7692 & -0.68 \\
\hline Metallurgy & 1.03 & 0.20 & 1.028 & 0.10 \\
\hline Construction & $.3668 * * *$ & -4.23 & .5439 & -0.82 \\
\hline Restaurants & $1.655^{*}$ & 1.87 & 1.097 & 0.35 \\
\hline Transports & 1.160 & 0.72 & 1.351 & 0.95 \\
\hline Insurance, finance & 1.200 & 0.83 & $1.860 * *$ & 2.17 \\
\hline Public administration & 1.398 & 1.59 & $1.970^{* * *}$ & 2.61 \\
\hline Education & .7332 & -1.15 & .8140 & -0.82 \\
\hline Health & 1.351 & 1.13 & 1.424 & 1.59 \\
\hline Culture, sport, leisure & 1.284 & 0.77 & $2.477 * * *$ & 3.45 \\
\hline Others & 1.398 & 1.31 & .9051 & -0.38 \\
\hline Average Probability & \multicolumn{2}{|c|}{.0520} & \multicolumn{2}{|c|}{.0506} \\
\hline Pseudo R-squared & \multicolumn{2}{|c|}{.1452} & \multicolumn{2}{|c|}{.1204} \\
\hline N. of observations & \multicolumn{2}{|c|}{14,948} & \multicolumn{2}{|c|}{12,053} \\
\hline
\end{tabular}

Notes: (i) * signals significant at the $10 \%$ level, $* *$ signals significant at the $5 \%$ level, and $* * *$ signals significant at the $1 \%$ level; (ii) the reference individual is a worker with less than primary education, aged less than 30 years, who has not a second activity, has always resided in Portugal, is working full-time in the private sector, in a firm with more than 500 workers, in the commerce sector, and in the North region of Portugal; (iii) control variables are included for region and quarter; (iv) standard errors are obtained using White's (1981) method. 
Table 4: Selection into various forms of training - Males

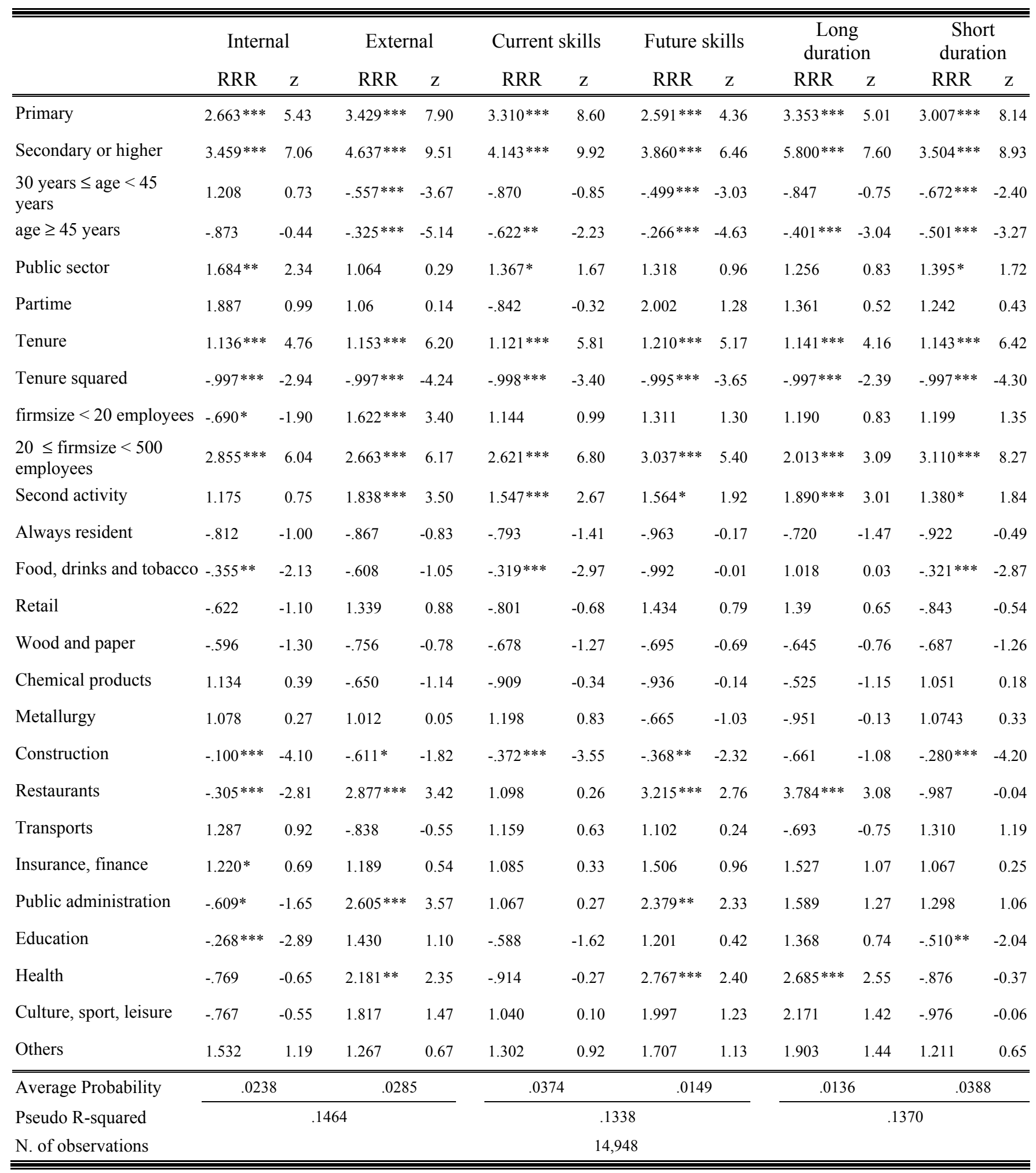

Notes: (i) * signals significant at the $10 \%$ level, ** signals significant at the $5 \%$ level, and $* * *$ signals significant at the $1 \%$ level; (ii) the reference individual is a worker with less than primary education, aged less than 30 years, who has not a second activity, has always resided in Portugal, is working full-time in the private sector, in a firm with more than 500 workers, in the commerce sector, and in the North region of Portugal; (iii) control variables are included for region and quarter; (iv) standard errors are obtained using White's (1981) method. 
Table 5: Selection into various forms of training - Females

\begin{tabular}{|c|c|c|c|c|c|c|c|c|c|c|c|c|}
\hline & \multicolumn{2}{|c|}{ Internal } & \multicolumn{2}{|c|}{ External } & \multicolumn{2}{|c|}{ Current skills } & \multicolumn{2}{|c|}{ Future skills } & \multicolumn{2}{|c|}{$\begin{array}{l}\text { Long } \\
\text { duration }\end{array}$} & \multicolumn{2}{|c|}{$\begin{array}{c}\text { Short } \\
\text { duration }\end{array}$} \\
\hline & RRR & $\mathrm{Z}$ & RRR & $\mathrm{Z}$ & RRR & $\mathrm{Z}$ & RRR & $\mathrm{Z}$ & RRR & $\mathrm{Z}$ & RRR & $\mathrm{Z}$ \\
\hline Primary & $3.273 * * *$ & 4.88 & $3.57 * * *$ & 6.52 & $3.955 * * *$ & 7.94 & $2.194 * *$ & 2.33 & $3.532 * * *$ & 3.55 & $3.520 * * *$ & 7.45 \\
\hline Secondary or higher & $2.910 * * *$ & 4.71 & $4.202 * * *$ & 7.68 & $3.818 * * *$ & 8.05 & $3.703 * * *$ & 4.37 & $6.292 * * *$ & 5.79 & $3.026 * * *$ & 6.58 \\
\hline $\begin{array}{l}30 \text { years } \leq \text { age }<45 \\
\text { years }\end{array}$ & 1.071 & 0.24 & $-.527 * * *$ & -3.61 & $-.683 * *$ & -2.20 & $-.523 * *$ & -2.16 & $-.512 * * *$ & -2.50 & $-.712 *$ & -1.87 \\
\hline age $\geq 45$ years & 1.043 & 0.13 & $-.445 * * *$ & -3.36 & $-.617 * *$ & -2.11 & $-.428 * *$ & -2.26 & $-.324 * * *$ & -3.09 & -.716 & -1.45 \\
\hline Public sector & 1.091 & 0.28 & 1.161 & 0.73 & 1.321 & 1.42 & -.733 & -0.87 & 1.080 & 0.27 & 1.173 & 0.76 \\
\hline Partime & -.497 & -1.13 & -.930 & -0.24 & -.660 & -1.24 & 1.36 & 0.66 & -.634 & -0.79 & -.923 & -0.26 \\
\hline Tenure & $1.129 * * *$ & 2.94 & $1.135 * * *$ & 4.92 & $1.138 * * *$ & 5.08 & $1.113 * * *$ & 2.53 & $1.100 * * *$ & 2.50 & $1.151 * * *$ & 5.32 \\
\hline Tenure squared & $-.997 * *$ & -2.16 & $-.997 * * *$ & -3.41 & $-.997 * * *$ & -3.74 & -.998 & -1.40 & -.999 & -0.92 & $-.996 * * *$ & -4.27 \\
\hline firmsize $<20$ employees & -.951 & -0.23 & 1.169 & 1.15 & 1.067 & 0.49 & 1.253 & 0.98 & -.783 & -1.05 & $1.273 *$ & 1.81 \\
\hline $\begin{array}{l}20 \leq \text { firmsize }<500 \\
\text { employees }\end{array}$ & $3.466 * * *$ & 6.09 & $2.147 * * *$ & 4.69 & $2.498 * * *$ & 6.29 & $2.642 * * *$ & 3.53 & $2.188 * * *$ & 3.53 & $2.747 * * *$ & 6.49 \\
\hline Second activity & $2.219 * *$ & 2.27 & $2.240 * * *$ & 3.46 & $1.765 * *$ & 2.31 & $3.567 * * *$ & 4.02 & $3.115 * * *$ & 3.72 & $1.741 * *$ & 2.18 \\
\hline Always resident & $-.561 * * *$ & -2.61 & 1.145 & 0.77 & -.962 & -0.24 & -.736 & -1.08 & 1.006 & 0.03 & -.850 & -1.00 \\
\hline Food, drinks and tobacco & $-.287 *$ & -1.80 & -.648 & -0.87 & -.596 & -1.13 & -.270 & -1.23 & $-.174 * *$ & -2.22 & -.577 & -1.21 \\
\hline Retail & -.725 & -0.78 & $-.529 *$ & -1.88 & -.628 & -1.60 & -.523 & -1.10 & -.764 & -0.48 & $-.555 * *$ & -1.99 \\
\hline Wood and paper & $-.233 *$ & -1.70 & 1.782 & 1.48 & 1.053 & 0.11 & 1.813 & 1.05 & 1.391 & 0.51 & 1.236 & 0.48 \\
\hline Chemical products & 1.314 & 0.53 & -.509 & -1.16 & -.681 & -0.84 & 1.097 & 0.14 & -- & -- & 1.042 & 0.11 \\
\hline Metallurgy & 1.742 & 1.29 & -.653 & -1.10 & 1.271 & 0.80 & -.254 & -1.30 & 1.364 & 0.59 & -.933 & -0.21 \\
\hline Construction & -- & -- & -.770 & -0.35 & -.386 & -0.93 & 1.069 & 0.06 & -- & -- & -.701 & -0.48 \\
\hline Restaurants & -.551 & -1.32 & 1.391 & 1.06 & -.982 & -0.05 & 1.470 & 0.80 & 2.120 & 1.59 & -.865 & -0.44 \\
\hline Transports & 1.972 & 1.48 & -.986 & -0.03 & 1.597 & 1.39 & $-.263 *$ & -1.70 & 1.153 & 0.24 & 1.4601 & 1.06 \\
\hline Insurance, finance & $2.163 *$ & 1.80 & 1.630 & 1.35 & $1.789 *$ & 1.83 & 1.764 & 1.00 & $2.328 *$ & 1.69 & 1.669 & 1.55 \\
\hline Public administration & $2.167^{*}$ & 1.66 & $1.783 *$ & 1.89 & $1.776 * *$ & 1.98 & $2.413 *$ & 1.68 & $2.947 * *$ & 2.33 & $1.666^{*}$ & 1.68 \\
\hline Education & $-.470 *$ & -1.70 & -.982 & -0.06 & -.802 & -0.78 & -.736 & -0.58 & 1.408 & 0.76 & -.620 & -1.62 \\
\hline Health & -.865 & -0.37 & $1.706 * *$ & 2.04 & 1.123 & 0.45 & $2.471 * *$ & 2.30 & $2.480 * *$ & 2.34 & 1.105 & 0.37 \\
\hline Culture, sport, leisure & 1.646 & 0.94 & $2.857 * * *$ & 3.54 & $2.367 * * *$ & 2.82 & $2.650 *$ & 1.94 & $3.453 * * *$ & 2.51 & $2.200 * * *$ & 2.60 \\
\hline Others & $-.298 * * *$ & -2.64 & 1.205 & 0.63 & 1.022 & 0.08 & -.542 & -1.01 & 1.053 & 0.10 & -.843 & -0.58 \\
\hline Average Probability & \multicolumn{2}{|c|}{.0191} & \multicolumn{2}{|c|}{.0316} & \multicolumn{2}{|c|}{.0398} & \multicolumn{2}{|c|}{.0108} & \multicolumn{2}{|l|}{.0139} & \multicolumn{2}{|c|}{.0368} \\
\hline Pseudo R-squared & \multicolumn{4}{|c|}{.1216} & \multicolumn{4}{|c|}{.1156} & \multicolumn{4}{|c|}{.1195} \\
\hline N. of observations & \multicolumn{8}{|c|}{12,053} & & & & \\
\hline
\end{tabular}

Notes: (i) * signals significant at the $10 \%$ level, ** signals significant at the $5 \%$ level, and $* * *$ signals significant at the $1 \%$ level; (ii) the reference individual is a worker with less than primary education, aged less than 30 years, who has not a second activity, has always resided in Portugal, is working full-time in the private sector, in a firm with more than 500 workers, in the commerce sector, and in the North region of Portugal; (iii) control variables are included for region and quarter; (iv) standard errors are obtained using White's (1981) method; (v) in some cases, women in construction and chemical products occupations were dropped from the estimating sub-sample, for the incidence of one of the training categories within those occupations was exactly zero. 
Table 6. Hausman test for the IIA assumption

\begin{tabular}{llrrrrr}
\hline \hline \multirow{2}{*}{ Classification } & \multirow{2}{*}{ Omitted category } & \multicolumn{2}{c}{ Chi-squared } & & \multicolumn{2}{c}{ Prob>chi-squared } \\
\cline { 3 - 4 } & & Men & Women & & Men & Women \\
\hline \hline Providing institution & Internal training & -1.14 & -2.21 & -- & -- \\
Purpose of the training & Current skills & 1.71 & -1.33 & & 1.000 & -- \\
Duration & Long duration &. .41 & -.62 & & 1.000 & - \\
\hline \hline
\end{tabular}

The Hausman test is based on estimating the multinomial logit for the full sample and for a restricted sample, where the restricted sample results from dropping the observations corresponding to one of the alternatives of the dependent variable (omitted category). The statistic is

$$
\chi^{2}=\left(\beta_{r}-\beta_{u}\right)^{\prime}\left[\hat{V}_{r}-\hat{V}_{u}\right]\left(\beta_{r}-\beta_{u}\right)
$$

where $r$ indicates the estimators based on the restricted sample, $u$ indicates the estimator of the unrestricted sample, and $\boldsymbol{V}_{\boldsymbol{r}}$ and $\boldsymbol{V}_{\boldsymbol{u}}$ are the respective estimates of the asymptotic covariance matrices. The statistic has a chi-squared distribution with K-1 degrees of freedom, where $\mathrm{K}$ is the number of regressors. The null hypothesis, $\boldsymbol{H}_{\boldsymbol{0}}$ states that the difference in the coefficients is not systematic (IIA assumption). Negative values of the statistic must be interpreted as strong evidence in favor of the null hypothesis. 
Table 7: Returns on training - OLS and Treatment Effects model

\begin{tabular}{|c|c|c|c|c|c|c|c|c|}
\hline & \multicolumn{4}{|c|}{ Men } & \multicolumn{4}{|c|}{ Women } \\
\hline & \multicolumn{2}{|c|}{ OLS } & \multicolumn{2}{|c|}{$\begin{array}{l}\text { Treatment } \\
\text { Effects }\end{array}$} & \multicolumn{2}{|c|}{ OLS } & \multicolumn{2}{|c|}{$\begin{array}{l}\text { Treatment } \\
\text { Effects }\end{array}$} \\
\hline & Coefficient & t-ratio & Coefficient & t-ratio & Coefficient & t-ratio & Coefficient & t-ratic \\
\hline Training & $.1190 * * *$ & 7.55 & $.2183 * * *$ & 3.18 & $.0815^{* * *}$ & 5.33 & $.3649 * * *$ & 4.31 \\
\hline Primary & $.1921 * * *$ & 20.15 & $.1857 * * *$ & 17.26 & $.2028 * * *$ & 20.70 & $.1869 * * *$ & 16.97 \\
\hline Secondary & $.3307 * * *$ & 26.96 & $.3212 * * *$ & 22.04 & $.3370 * * *$ & 30.65 & $.3213 * * *$ & 27.55 \\
\hline Tertiary & $.8828 * * *$ & 51.71 & $.8721 * *$ & 44.78 & $.9101 * * *$ & 67.69 & $.8884 * * *$ & 57.54 \\
\hline Experience & $-.0254 * * *$ & 27.28 & $.0252 * * *$ & 26.35 & $.0206^{* * *}$ & 20.24 & $.0204 * * *$ & 20.01 \\
\hline Experience squared (x 1000) & $.357 * * *$ & -20.99 & $-.405 * * *$ & -20.24 & $-.336 * * *$ & -16.18 & $-.3608 * * *$ & -15.97 \\
\hline Public sector & $.1046 * * *$ & 7.79 & $.1011 * * *$ & 7.35 & $.1845^{* * *}$ & 14.75 & $.1813 * * *$ & 14.20 \\
\hline Partime & $.1541 * * *$ & 3.61 & $.1518 * * *$ & 3.54 & $.1753 * * *$ & 10.02 & $.1763 * * *$ & 9.90 \\
\hline 6 years $\leq$ tenure $<26$ years & $.0821 * * *$ & 11.02 & $.0784 * * *$ & 9.93 & $.1111^{* * *}$ & 15.13 & $.1040 * * *$ & 12.95 \\
\hline tenure $>26$ years & $.2332 * * *$ & 17.39 & $.2282 * * *$ & 16.43 & $.2825^{* * *}$ & 19.94 & $.2733 * * *$ & 18.16 \\
\hline firmsize $<20$ employees & $-.0637 * * *$ & -8.21 & $-.0648^{* * *}$ & -8.26 & $-.0425^{* * *}$ & -5.33 & $-.0439 * * *$ & -5.44 \\
\hline $20 \leq$ firmsize $<500$ employees & $.0417 * * *$ & 3.87 & $.0329 * * *$ & 2.62 & .0071 & .72 & -.0082 & -.76 \\
\hline Food, drinks and tobacco & $-.0337 *$ & -1.82 & $-.0310 *$ & -1.69 & $-.0495 * * *$ & -2.55 & $-.0440 * *$ & -2.22 \\
\hline Retail & $-.0816^{* * *}$ & -6.18 & $-.0818^{* * *}$ & -6.13 & $-.0736 * * *$ & -5.83 & $-.0695 * * *$ & -5.34 \\
\hline Wood and paper & -.0186 & -1.20 & -.0172 & -1.11 & -.0113 & -.45 & -.0134 & -.52 \\
\hline Chemical products & $.0498 * * *$ & 2.95 & $.0499 * * *$ & 2.98 & $.0518^{* *}$ & 2.33 & $.0561 * *$ & 2.45 \\
\hline Metallurgy & -.0018 & -.17 & -.0021 & -.19 & $.0502 * * *$ & 3.35 & $.0500 * * *$ & 3.27 \\
\hline Construction & $.0344 * * *$ & 3.25 & $.0357 * * *$ & 3.34 & $.0745^{* *}$ & 2.20 & $.0816 * *$ & 2.34 \\
\hline Restaurants & $-.1218 * * *$ & -5.70 & $-.1248 * * *$ & -5.75 & -.0214 & -1.32 & -.0234 & -1.42 \\
\hline Transports & $.0977 * * *$ & 5.90 & $.0971 * * *$ & 5.88 & $.1573 * * *$ & 5.70 & $.1547 * * *$ & 5.54 \\
\hline Insurance, finance & $.3570 * * *$ & 16.55 & $.3553 * * *$ & 16.47 & $.3194 * * *$ & 10.50 & $.3077 * * *$ & 9.86 \\
\hline Public administration & $.0323 *$ & 1.89 & $.0292 *$ & 1.69 & $.0968 * * *$ & 5.10 & $.0835 * * *$ & 4.17 \\
\hline Education & $.0629 * * *$ & 2.71 & $.0656 * * *$ & 2.76 & $.1025 * * *$ & 6.39 & $.1093 * * *$ & 6.56 \\
\hline Health & -.0171 & -.80 & -.0204 & -.95 & -.0190 & -1.38 & -.0214 & -1.50 \\
\hline Culture, sport, leisure & .0479 & 1.35 & .0462 & 1.30 & -.0009 & -.04 & -.0145 & -.67 \\
\hline Others & .0135 & .71 & .0115 & .60 & .0079 & .57 & .0089 & .62 \\
\hline Selection term & & & -.0497 & -1.50 & & & $-.1397 * * *$ & -3.32 \\
\hline N. of observations & & & & & & & & \\
\hline
\end{tabular}

Notes: (i) * signals significant at the $10 \%$ level, ** signals significant at the $5 \%$ level, and *** signals significant at the $1 \%$ level; (ii) the reference individual is an untrained worker with less than primary education, less than 6 years of tenure, working full-time in the private sector, in a firm with more than 500 workers, in a commerce occupation, and in the North region of Portugal; (iii) control variables are included for region and quarter; (iv) standard errors are obtained using White's (1981) method. 
Table 8: Returns on training - OLS and Treatment effects model with interaction terms

\begin{tabular}{|c|c|c|c|c|c|c|c|c|}
\hline & \multicolumn{4}{|c|}{ Men } & \multicolumn{4}{|c|}{ Women } \\
\hline & \multicolumn{2}{|c|}{ OLS } & \multicolumn{2}{|c|}{$\begin{array}{l}\text { Treatment } \\
\text { Effects }\end{array}$} & \multicolumn{2}{|l|}{ OLS } & \multicolumn{2}{|c|}{$\begin{array}{l}\text { Treatment } \\
\text { Effects }\end{array}$} \\
\hline & Coefficient & t-ratio & Coefficient & t-ratio & Coefficient & t-ratio & Coefficient & t-ratio \\
\hline Training & $.1781 * * *$ & 3.74 & $.4065 * * *$ & 2.86 & $.2171 * * *$ & 3.68 & $.5912 * * *$ & 7.03 \\
\hline Primary & $.1888^{* * *}$ & 19.29 & $.1786 * * *$ & 16.63 & $.2007 * * *$ & 19.95 & $.1860^{* * *}$ & 17.35 \\
\hline Secondary & $.3333 * * *$ & 25.80 & $.3181 * * *$ & 22.12 & $.3394 * * *$ & 29.91 & $.3243^{* * *}$ & 27.61 \\
\hline Tertiary & $.8900 * * *$ & 49.46 & $.8723 * * *$ & 43.60 & $.9178^{* * *}$ & 65.95 & $.8970 * * *$ & 59.70 \\
\hline Experience & $.0251 * * *$ & 26.68 & $.0248 * * *$ & 25.91 & $.0203^{* * *}$ & 19.85 & $.0203 * * *$ & 19.74 \\
\hline Experience squared (x 1000) & $-.413 * * *$ & -20.58 & $-.3982 * * *$ & -19.93 & $-.362 * * *$ & -15.98 & $-.3597 * * *$ & -15.86 \\
\hline Public sector & $.0998 * * *$ & 7.42 & $.0935 * * *$ & 6.71 & $.1813^{* * *}$ & 14.46 & $.1788^{* * *}$ & 13.89 \\
\hline Partime & $.1560 * * *$ & 3.78 & $.1508 * * *$ & 3.64 & $.1771 * * *$ & 10.10 & $.1784 * * *$ & 10.03 \\
\hline 6 years $\leq$ tenure $<26$ years & $.0819 * * *$ & 10.98 & $.0749 * * *$ & 9.61 & $.1113^{* * *}$ & 15.08 & $.1036^{* * *}$ & 13.21 \\
\hline tenure $\geq 26$ years & $.2310 * * *$ & 17.19 & $.2210 * * *$ & 15.80 & $.2773^{* * *}$ & 19.67 & $.2668 * * *$ & 18.03 \\
\hline firmsize $<20$ employees & $-.0632 * * *$ & -8.16 & $.0655 * * *$ & -8.27 & $-.0423 * * *$ & -5.31 & $-.0437 * * *$ & -5.39 \\
\hline $20 \leq$ firmsize $<500$ employees & $.0403 * * *$ & 3.77 & $.0236 *$ & 1.86 & .0063 & .65 & -.0105 & -1.00 \\
\hline Selection term & & & $-.1004 *$ & -1.72 & & & $-.1638 * * *$ & -5.83 \\
\hline \multicolumn{9}{|c|}{ Interaction terms } \\
\hline Primary & .0278 & .65 & -.0144 & -.32 & -.0030 & -.06 & -.0747 & -1.58 \\
\hline Secondary & -.0190 & -.44 & -.0664 & -1.40 & -.0449 & -.86 & $-.1139 * *$ & -2.19 \\
\hline Tertiary & -.0817 & -1.41 & $-.1312 * *$ & -2.14 & $-.1403 * * *$ & -2.67 & $-.2169 * * *$ & -4.15 \\
\hline experience $<6$ years & $-.1614 * * *$ & -3.65 & $-.1165 * *$ & -2.45 & $-.1838 * * *$ & -3.47 & $-.1332 * *$ & -2.49 \\
\hline 6 years $\leq$ experience $<26$ years & -.0490 & -1.45 & -.0391 & -1.17 & $-.1037 * * *$ & -2.67 & $-.0864 * *$ & -2.23 \\
\hline Food, drinks and tobacco & .1664 & 1.15 & .1875 & 1.36 & .0030 & .03 & .0307 & .27 \\
\hline Retail & $-.1510 *$ & -1.70 & $-.1593 *$ & -1.74 & -.0774 & -1.30 & -.0795 & -1.26 \\
\hline Wood and paper & .0669 & .75 & .0714 & .79 & .0865 & 1.06 & .0547 & .65 \\
\hline Chemical products & .1264 & 1.32 & .1279 & 1.34 & $-.1700 *$ & -1.80 & -.1559 & -1.52 \\
\hline Metallurgy & -.0258 & -.42 & -.0279 & -.46 & -.0286 & -.40 & -.0408 & -.56 \\
\hline Construction & .0174 & .22 & .0616 & .77 & $-.3369 * * *$ & -3.52 & $-.3301 * * *$ & -2.70 \\
\hline Restaurants & $-.1655 * * *$ & -2.53 & $-.1879 * * *$ & -2.79 & $-.1816^{* *}$ & -2.21 & $-.1823 * *$ & -2.18 \\
\hline Transports & .0528 & .71 & .0357 & .48 & .0834 & .64 & .0794 & .60 \\
\hline Insurance, finance & .0726 & 1.01 & .0556 & .77 & .0971 & 1.04 & .0706 & .76 \\
\hline Public administration & -.0189 & -.37 & -.0502 & -.97 & .0255 & .43 & -.0105 & -.17 \\
\hline Education & $-.1492 *$ & -1.95 & $-.1590 * *$ & -2.06 & -.0130 & -.22 & -.0140 & -.23 \\
\hline Health & -.0139 & -.17 & -.0475 & -.57 & .0611 & .96 & .0317 & .49 \\
\hline Culture, sport, leisure & .0150 & .10 & .0047 & .03 & .0018 & .02 & -.0383 & -.46 \\
\hline Others & .0922 & 1.34 & .0760 & 1.12 & .0411 & .59 & .0372 & .52 \\
\hline N. of observations & & & 948 & & & & & \\
\hline
\end{tabular}

Notes: (i) * signals significant at the $10 \%$ level, ** signals significant at the $5 \%$ level, and $* * *$ signals significant at the $1 \%$ level; (ii) the reference individual is an untrained worker with less than primary education, less than 6 years of tenure and experience, working full-time in the private sector, in a firm with more than 500 workers, in a commerce occupation, and in the North region of Portugal; (iii) control variables are included for region and quarter; (iv) standard errors are obtained using White's (1981) method. 
Table 9: Returns on training in the Private sector- OLS and Treatment effects model with interaction terms

\begin{tabular}{|c|c|c|c|c|c|c|c|c|}
\hline & \multicolumn{4}{|c|}{ Men } & \multicolumn{4}{|c|}{ Women } \\
\hline & \multicolumn{2}{|c|}{ OLS } & \multicolumn{2}{|c|}{$\begin{array}{c}\text { Treatment } \\
\text { Effects }\end{array}$} & \multicolumn{2}{|c|}{ OLS } & \multicolumn{2}{|c|}{$\begin{array}{c}\text { Treatment } \\
\text { Effects }\end{array}$} \\
\hline & Coefficient & t-ratio & Coefficient & t-ratio & Coefficient & t-ratio & Coefficient & t-ratio \\
\hline Training & $.1734 * * *$ & 4.71 & $.266 * *$ & 1.99 & $.1852 * * *$ & 3.50 & $.6075^{* * *}$ & 8.61 \\
\hline Primary & $.1738 * * *$ & 16.03 & $.1647 * * *$ & 11.27 & $.1493 * * *$ & 13.14 & $.1315 * * *$ & 10.99 \\
\hline Secondary & $.3010 * * *$ & 19.75 & $.2849 * * *$ & 12.55 & $.2769^{* * *}$ & 21.95 & $.2579^{* * *}$ & 20.03 \\
\hline Tertiary & $.8466 * * *$ & 33.15 & $.8294 * * *$ & 24.88 & $.7961 * * *$ & 31.00 & $.7622 * * *$ & 28.10 \\
\hline Experience & $.0242 * * *$ & 23.67 & $.0240 * * *$ & 22.29 & $.0178^{* * *}$ & 15.36 & $.0177^{* * *}$ & 15.23 \\
\hline Experience squared (x 1000) & $-.325 * * *$ & -17.90 & $-.3834 * * *$ & -16.93 & $-.345 * * *$ & -13.03 & $-.3345 * * *$ & -12.87 \\
\hline Partime & $.1228 * * *$ & 2.64 & $.1149 * *$ & 2.44 & $.1641 * * *$ & 8.49 & $.1635 * * *$ & 8.23 \\
\hline 6 years $\leq$ tenure $<26$ years & $.0693 * * *$ & 8.59 & $.0630 * * *$ & 6.29 & $.0808 * * *$ & 9.84 & $.0733 * * *$ & 8.58 \\
\hline tenure $\geq 26$ years & $.2003^{* * *}$ & 13.23 & $.1921 * * *$ & 11.04 & $.1925^{* * *}$ & 10.56 & $.1824 * * *$ & 9.81 \\
\hline firmsize $<20$ employees & $-.0681 * * *$ & -8.24 & $-.0700 * * *$ & -8.10 & $-.0512 * * *$ & -5.62 & $-.0549 * * *$ & -5.92 \\
\hline $20 \leq$ firmsize $<500$ employees & $.0412 * * *$ & 3.39 & .0261 & 1.34 & .0085 & .78 & -.0056 & -.49 \\
\hline Selection term & & & -.0405 & -.738 & & & $-.1853^{* * *}$ & -6.99 \\
\hline \multicolumn{9}{|c|}{ Interaction terms } \\
\hline Primary & .0351 & .64 & -.0149 & -.21 & .0433 & .87 & -.0232 & -.45 \\
\hline Secondary & -.0077 & -.14 & -.0696 & -.88 & .0704 & 1.36 & .0020 & .04 \\
\hline Tertiary & -.0519 & -.63 & -.1115 & -1.16 & .0386 & .50 & -.0245 & -.32 \\
\hline experience $<6$ years & $-.2161 * * *$ & -4.12 & $-.1646 * *$ & -2.25 & $-.2961 * * *$ & -4.16 & $-.2568 * * *$ & -3.77 \\
\hline 6 years $\leq$ experience $<26$ years & -.0327 & -.70 & -.0188 & -.40 & $-.1284 * *$ & -2.06 & $-.1205^{* *}$ & -2.00 \\
\hline N. of observations & \multicolumn{4}{|c|}{11,697} & \multicolumn{4}{|c|}{8,369} \\
\hline
\end{tabular}

Notes: (i) * signals significant at the $10 \%$ level, ** signals significant at the $5 \%$ level, and $* * *$ signals significant at the $1 \%$ level; (ii) the reference individual is an untrained worker with less than primary education, less than 6 years of tenure and experience, working full-time in the private sector, in a firm with more than 500 workers, in a commerce occupation, and in the North region of Portugal; (iii) control variables are included for region and quarter; (iv) standard errors are obtained using White's (1981) method. 
Table 10: Returns on training in the Public sector- OLS and Treatment effects model with interaction terms

\begin{tabular}{|c|c|c|c|c|c|c|c|c|}
\hline & \multicolumn{4}{|c|}{ Men } & \multicolumn{4}{|c|}{ Women } \\
\hline & \multicolumn{2}{|c|}{ OLS } & \multicolumn{2}{|c|}{$\begin{array}{c}\text { Treatment } \\
\text { Effects }\end{array}$} & \multicolumn{2}{|c|}{ OLS } & \multicolumn{2}{|c|}{$\begin{array}{c}\text { Treatment } \\
\text { Effects }\end{array}$} \\
\hline & Coefficient & t-ratio & Coefficient & t-ratio & Coefficient & t-ratio & Coefficient & t-ratio \\
\hline Training & $.1606^{* * *}$ & 3.06 & $.2852 *$ & 1.94 & $.2943 * * *$ & 3.73 & $.6501^{* * *}$ & 5.48 \\
\hline Primary & $.2609 * * *$ & 11.82 & $.2461 * * *$ & 8.96 & $.3219 * * *$ & 16.14 & $.3000 * * *$ & 13.37 \\
\hline Secondary & $.4385^{* * *}$ & 18.29 & $.4245^{* * *}$ & 15.18 & $.4912^{* * *}$ & 21.72 & $.4743^{* * *}$ & 19.69 \\
\hline Tertiary & $.9906 * * *$ & 38.45 & $.9767 * * *$ & 32.20 & $1.047 * * *$ & 66.41 & $1.031 * * *$ & 58.35 \\
\hline Experience & $.0269^{* * *}$ & 10.33 & $.0266 * * *$ & 10.17 & $.0220^{* * *}$ & 10.90 & $.0220^{* * *}$ & 10.73 \\
\hline Experience squared (x 1000) & $-.367 * * *$ & -8.38 & $-.4010 * * *$ & -8.18 & $-.329 * * *$ & -7.05 & $-.3028 * * *$ & -6.94 \\
\hline Partime & $.3268 * * *$ & 3.27 & $.3305 * * *$ & 3.27 & $.2604 * * *$ & 6.26 & $.2642 * * *$ & 6.34 \\
\hline 6 years $\leq$ tenure $<26$ years & $.1681^{* * *}$ & 8.58 & $.1590^{* * *}$ & 7.40 & $.2046^{* * *}$ & 13.21 & $.1931^{* * *}$ & 11.67 \\
\hline tenure $\geq 26$ years & $.3427 * * *$ & 11.53 & $.3304 * * *$ & 10.06 & $.3753 * * *$ & 16.31 & $.3632 * * *$ & 14.73 \\
\hline Firmsize $<20$ employees & $-.0444 * *$ & -2.02 & $-.0470 * *$ & -2.12 & $-.0273 *$ & -1.81 & $-.0264 *$ & -1.71 \\
\hline $20 \leq$ firmsize $<500$ employees & .0206 & .90 & .0044 & .16 & .0083 & .40 & -.0167 & -.69 \\
\hline Selection term & & & -.0850 & -.93 & & & $-.1618 * * *$ & -3.41 \\
\hline \multicolumn{9}{|c|}{ Interaction terms } \\
\hline Primary & .0201 & .30 & -.0008 & -.01 & -.1263 & -1.35 & $-.1893 * *$ & -1.96 \\
\hline Secondary & -.0262 & -.37 & -.0457 & -.61 & $-.2365 * * *$ & -2.56 & $-.2905 * * *$ & -3.08 \\
\hline Tertiary & $-.1542 * *$ & -2.12 & $-.1788 * *$ & -2.37 & $-.3140 * * *$ & -3.72 & $-.3882 * * *$ & -4.41 \\
\hline experience $<6$ years & -.0046 & -.05 & .0100 & .12 & .1213 & 1.39 & $.1557 *$ & 1.77 \\
\hline 6 years $\leq$ experience $<26$ years & -.0643 & -1.26 & -.0639 & -1.27 & -.0349 & -.73 & -.0198 & -.39 \\
\hline N. of observations & \multicolumn{4}{|c|}{3,251} & \multicolumn{4}{|c|}{3,684} \\
\hline
\end{tabular}

Notes: (i) * signals significant at the $10 \%$ level, ** signals significant at the $5 \%$ level, and *** signals significant at the $1 \%$ level; (ii) the reference individual is an untrained worker with less than primary education, less than 6 years of tenure and experience, working full-time in the public sector, in a firm with more than 500 workers, in a commerce occupation, and in the North region of Portugal; (iii) control variables are included for region and quarter; (iv) standard errors are obtained using White's (1981) method. 
Table 11: OLS and treatment effects estimates of different types of training

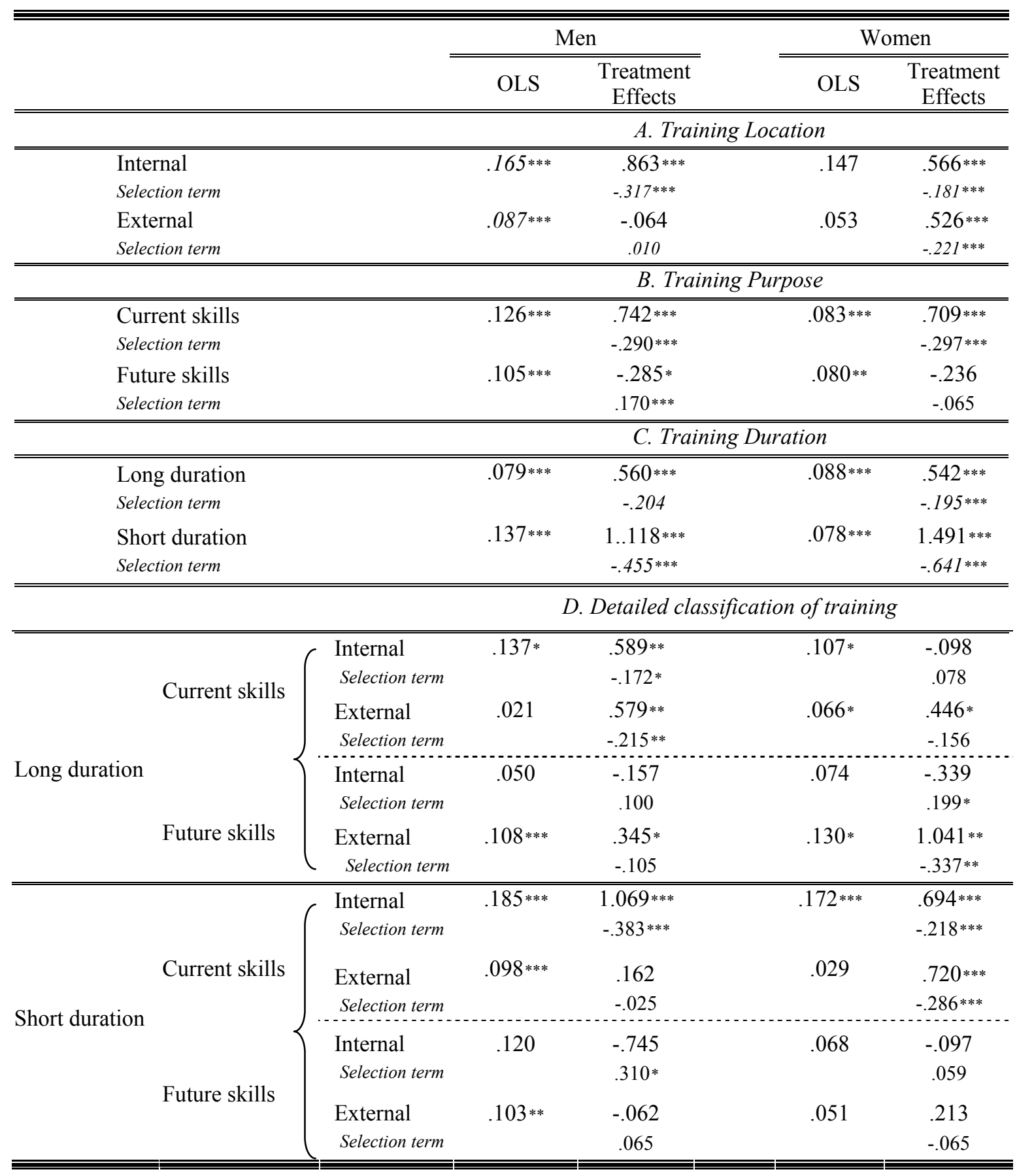

Notes: (i) * signals significant at the $10 \%$ level, ** signals significant at the $5 \%$ level, and $* * *$ signals significant at the $1 \%$ level. 
Table 12: OLS estimates of different types of training

\begin{tabular}{lll}
\hline \hline \multicolumn{1}{c}{ Training Content } & \multicolumn{1}{c}{ Men } & Women \\
\hline \hline Health and life sciences & $.2221^{* * *}$ & $.3298^{* * *}$ \\
Teachers and related professions & .0171 & $.0739 *$ \\
Technicians of physics and related areas & $.0957^{* * *}$ & .0156 \\
Technicians of other areas & $.1903^{* * *}$ & $.1079^{* * *}$ \\
Firm directors & $.4236^{* * *}$ & $.5403^{* * *}$ \\
Clerks and secretaries & $.1000^{* * *}$ & $.1025^{* * *}$ \\
Workers of personal services & $.0827^{* *}$ & .0303 \\
Agricultural workers and fishermen & .1281 & -.0269 \\
Workers of metallurgy & $.1078^{* *}$ & $.1955^{*}$ \\
Civil construction & .0498 & .0125 \\
Others & $.1237^{* * *}$ & -.0124 \\
\hline \hline
\end{tabular}

Notes: (i) * signals significant at the $10 \%$ level, $* *$ signals significant at the $5 \%$ level, and $* * *$ signals significant at the $1 \%$ level. 
Table 13: OLS wage equation with interaction terms - Males

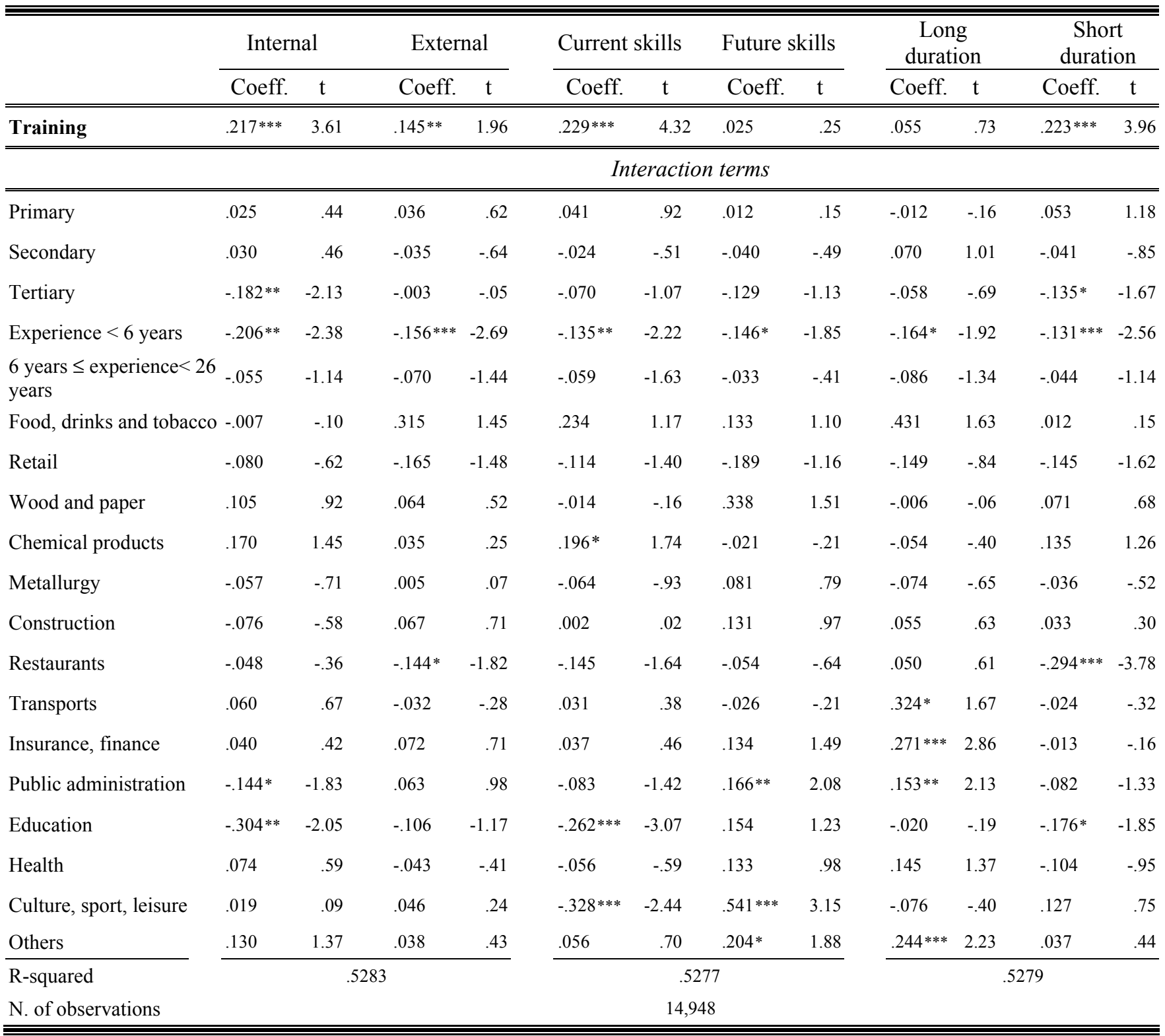

Notes: (i) * signals significant at the $10 \%$ level, ** signals significant at the $5 \%$ level, and $* * *$ signals significant at the $1 \%$ level; (ii) the reference individual is an untrained worker with less than primary education, less than 6 years of tenure and experience, working full-time in the private sector, in a firm with more than 500 workers, in a commerce occupation, and in the North region of Portugal; (iii) control variables are included for region and quarter; (iv) standard errors are obtained using White's (1981) method. 
Table 14: Treatment effects model with interaction terms - Males

\begin{tabular}{|c|c|c|c|c|c|c|c|c|c|c|c|c|}
\hline & \multicolumn{2}{|c|}{ Internal } & \multicolumn{2}{|c|}{ External } & \multicolumn{2}{|c|}{ Current skills } & \multicolumn{2}{|c|}{ Future skills } & \multicolumn{2}{|c|}{$\begin{array}{c}\text { Long } \\
\text { duration }\end{array}$} & \multicolumn{2}{|c|}{$\begin{array}{c}\text { Short } \\
\text { duration }\end{array}$} \\
\hline & Coeff. & $\mathrm{t}$ & Coeff. & $\mathrm{t}$ & Coeff. & $\mathrm{t}$ & Coeff. & $\mathrm{t}$ & Coeff. & $\mathrm{t}$ & Coeff. & $\mathrm{t}$ \\
\hline Training & $1.164 * * *$ & 6.30 & .213 & 1.09 & $1.36 * * *$ & 8.56 & $-.605 * *$ & -2.30 & $.472 *$ & 1.73 & $.889 * * *$ & 6.00 \\
\hline \multirow{2}{*}{ Selection term } & $-.403 * * *$ & -5.90 & -.027 & -.38 & $-.481 * * *$ & -7.71 & $.237 * * *$ & 2.86 & -.143 & -1.55 & $-.286^{* * *}$ & -4.86 \\
\hline & \multicolumn{12}{|c|}{ Interaction terms } \\
\hline Primary & $-.153 * *$ & -2.41 & .033 & .54 & $-.130 * * *$ & -2.62 & -.041 & -.52 & -.068 & -.79 & -.058 & -1.23 \\
\hline Secondary & $-.156^{* *}$ & -2.14 & -.031 & -.53 & $-.207 * * *$ & -3.75 & -.064 & -.85 & .006 & .07 & $-.142 * * *$ & -2.69 \\
\hline Tertiary & $-.374 * * *$ & -4.15 & -.005 & -.06 & $-.297 * * *$ & -3.78 & -.075 & -.77 & -.128 & -1.30 & $-.256 * * *$ & -2.88 \\
\hline experience $<6$ years & .108 & .97 & $-.146 * * *$ & -2.55 & .001 & .01 & .009 & .12 & -.133 & -1.53 & -.031 & -.57 \\
\hline $\begin{array}{l}6 \text { years } \leq \text { experience }<26 \\
\text { years }\end{array}$ & .022 & .46 & -.060 & -1.24 & -.040 & -1.07 & .109 & 1.62 & -.087 & -1.35 & -.026 & -.67 \\
\hline Food, drinks and tobacco & .104 & 1.26 & .308 & 1.44 & .040 & .38 & $.457 * *$ & 2.27 & $.430 *$ & 1.72 & .084 & 1.00 \\
\hline Retail & .028 & .21 & -.154 & -1.39 & -.108 & -1.23 & -.096 & -.67 & -.173 & -.91 & -.152 & -1.57 \\
\hline Wood and paper & .087 & .62 & .070 & .57 & .011 & .11 & .290 & 1.14 & .027 & .22 & .065 & .58 \\
\hline Chemical products & .158 & 1.27 & .03 & .27 & .160 & 1.40 & .065 & .44 & -.067 & -.52 & .135 & 1.25 \\
\hline Metallurgy & -.064 & -.78 & .008 & .10 & -.078 & -1.15 & -.042 & -.30 & -.070 & -.62 & -.040 & -.56 \\
\hline Construction & $.284 * *$ & 1.96 & .062 & .67 & $.163 * *$ & 1.98 & .067 & .35 & .074 & .85 & .170 & 1.40 \\
\hline Restaurants & .055 & .32 & -.112 & -1.38 & -.139 & -1.59 & -.048 & -.42 & .009 & .10 & $-.302 * * *$ & -3.76 \\
\hline Transports & -.072 & -.71 & -.034 & -.31 & -.075 & -.83 & .187 & 1.43 & $.331 *$ & 1.69 & -.092 & -1.20 \\
\hline Insurance, finance & -.000 & -.00 & .064 & .64 & -.037 & -.43 & $.190 *$ & 1.67 & $.239 * *$ & 2.41 & -.046 & -.52 \\
\hline Public administration & -.129 & -1.53 & .074 & 1.11 & $-.132 * * *$ & -2.19 & $.172 *$ & 1.70 & $.122 *$ & 1.67 & $-.166 * * *$ & -2.56 \\
\hline Education & -.203 & -1.46 & -.082 & -.92 & $-.288 * * *$ & -3.12 & .158 & 1.19 & -.045 & -.38 & $-.163 *$ & -1.68 \\
\hline Health & .017 & .13 & -.027 & -.26 & -.031 & -.34 & .104 & .77 & .079 & .70 & -.125 & -1.15 \\
\hline Culture, sport, leisure & .011 & .05 & .061 & .32 & $-.289 *$ & -1.87 & $.557 * * *$ & 2.70 & -.111 & -.59 & .115 & .65 \\
\hline Others & .089 & .84 & .031 & .36 & .016 & .19 & .138 & 1.26 & $.221 * *$ & 1.98 & .031 & .37 \\
\hline N. of observations & & & & & & & & & & & & \\
\hline
\end{tabular}

Notes: (i) * signals significant at the $10 \%$ level, $* *$ signals significant at the $5 \%$ level, and $* * *$ signals significant at the $1 \%$ level; (ii) the reference individual is an untrained worker with less than primary education, less than 6 years of tenure and experience, working full-time in the private sector, in a firm with more than 500 workers, in a commerce occupation, and in the North region of Portugal; (iii) control variables are included for region and quarter; (iv) standard errors are obtained using White's (1981) method. 
Table 15: OLS wage equation with interaction terms - Females

\begin{tabular}{|c|c|c|c|c|c|c|c|c|c|c|c|c|}
\hline & \multicolumn{2}{|c|}{ Internal } & \multicolumn{2}{|c|}{ External } & \multicolumn{2}{|c|}{ Current skills } & \multicolumn{2}{|c|}{ Future skills } & \multicolumn{2}{|c|}{$\begin{array}{c}\text { Long } \\
\text { duration }\end{array}$} & \multicolumn{2}{|c|}{$\begin{array}{c}\text { Short } \\
\text { duration }\end{array}$} \\
\hline & Coeff. & $\mathrm{t}$ & Coeff. & $\mathrm{t}$ & Coeff. & $\mathrm{t}$ & Coeff. & $\mathrm{t}$ & Coeff. & $\mathrm{t}$ & Coeff. & $\mathrm{t}$ \\
\hline \multirow[t]{2}{*}{ Training } & $.214^{* *}$ & 2.08 & $.205 * * *$ & 2.85 & $.182 * * *$ & 2.91 & $.328 * * *$ & 2.86 & $.480 * * *$ & 3.66 & $.158 * * *$ & 2.64 \\
\hline & \multicolumn{12}{|c|}{ Interaction terms } \\
\hline Primary & -.057 & -.77 & .032 & .54 & .029 & .56 & -.014 & -.15 & -.055 & -.55 & .012 & .23 \\
\hline Secondary & -.031 & -.31 & -.036 & -.62 & .062 & 1.15 & $-.222 * * *$ & -2.60 & $-.189 *$ & $1.82^{-}$ & -.012 & -.20 \\
\hline Tertiary & $-.145^{*}$ & -1.67 & $-.106^{*}$ & -1.72 & -.091 & -1.64 & $-.226 * *$ & -2.35 & $-.262 * *$ & 2.36 & $-.129 * *$ & -2.12 \\
\hline Experience $<6$ years & $-.241 * *$ & -2.09 & $-.167 * * *$ & -2.76 & $-.242 * * *$ & -4.07 & -.102 & -1.10 & $-.234 * * *$ & $2.7 \overline{6}$ & $-.186 * * *$ & -2.77 \\
\hline $\begin{array}{l}6 \text { years } \leq \text { experience }<26 \\
\text { years }\end{array}$ & -.036 & -.54 & $-.131 * * *$ & -2.73 & $-.128 * * *$ & -3.10 & -.094 & -1.17 & $-.186 * * *$ & 2.46 & $-.089 *$ & -1.95 \\
\hline Food, drinks and tobacco & .130 & 1.00 & -.065 & -.55 & -.024 & -.20 & .063 & .43 & $-.234 *$ & $1.82^{-}$ & .050 & .42 \\
\hline Retail & -.141 & -1.24 & -.042 & -.57 & .016 & .25 & $-.254 * *$ & -2.45 & $-.216^{* *}$ & $2.1 \overline{7}^{-}$ & -.038 & -.55 \\
\hline Wood and paper & -.076 & -.57 & .108 & 1.28 & .007 & .09 & .125 & .98 & -.136 & -.66 & .141 & 1.60 \\
\hline Chemical products & -.089 & -.71 & $-.333 * * *$ & -3.46 & -.136 & -1.29 & $-.288 * * *$ & -2.84 & -- & -- & -.131 & -1.35 \\
\hline Metallurgy & .032 & .27 & -.112 & -1.36 & .009 & .13 & $-.361 * * *$ & -3.92 & -.081 & -.59 & -.019 & -.23 \\
\hline Construction & -- & -- & $-.297 * * *$ & -3.04 & $-.365 * * *$ & -5.29 & $-.348 * * *$ & -3.17 & -- & -- & $-.295 * * *$ & -3.00 \\
\hline Restaurants & $-.224 *$ & -1.86 & $-.165 *$ & -1.72 & -.129 & -1.59 & $-.244 *$ & -1.78 & -.231 & $1.48^{-}$ & $-.196^{* *}$ & -2.02 \\
\hline Transports & .149 & .68 & -.047 & -.53 & .006 & .06 & .269 & .49 & -.247 & $1.4 \overline{6}$ & .175 & 1.14 \\
\hline Insurance, finance & .199 & 1.38 & .040 & .36 & .106 & 1.01 & .003 & .02 & -.119 & -.73 & $.185^{*}$ & 1.80 \\
\hline Public administration & .044 & .42 & .005 & .08 & .010 & .15 & -.018 & -.18 & -.086 & -.76 & .057 & .85 \\
\hline Education & -.069 & -.58 & -.007 & -.11 & -.021 & -.34 & -.007 & .05 & -.052 & -.44 & -.004 & -.06 \\
\hline Health & .107 & .91 & .052 & .72 & .061 & .80 & .026 & .26 & .027 & .22 & .037 & .51 \\
\hline Culture, sport, leisure & .170 & 1.06 & -.051 & -.65 & .038 & .40 & -.099 & -.84 & -.148 & 1.23 & .038 & .37 \\
\hline Others & .207 & 1.41 & .027 & .37 & .023 & .33 & .092 & .51 & .054 & .31 & .052 & .76 \\
\hline R-squared & \multicolumn{4}{|c|}{.6787} & \multicolumn{4}{|c|}{.6787} & \multicolumn{4}{|c|}{.6786} \\
\hline N. of observations & \multicolumn{12}{|c|}{12,053} \\
\hline
\end{tabular}

Notes: (i) * signals significant at the $10 \%$ level, ** signals significant at the $5 \%$ level, and $* * *$ signals significant at the $1 \%$ level; (ii) the reference individual is an untrained worker with less than primary education, less than 6 years of tenure and experience, working full-time in the private sector, in a firm with more than 500 workers, in a commerce occupation, and in the North region of Portugal; (iii) control variables are included for region and quarter; (iv) standard errors are obtained using White's (1981) method; (v) in some cases, women in construction and chemical products occupations were dropped from the estimating sub-sample, for the incidence of one of the training categories within those occupations was exactly zero. 
Table 16: Returns on training - Treatment effects model with interaction terms - Females

\begin{tabular}{|c|c|c|c|c|c|c|c|c|c|c|c|c|}
\hline & \multicolumn{2}{|c|}{ Internal } & \multicolumn{2}{|c|}{ External } & \multicolumn{2}{|c|}{ Current skills } & \multicolumn{2}{|c|}{ Future skills } & \multicolumn{2}{|c|}{$\begin{array}{c}\text { Long } \\
\text { duration }\end{array}$} & \multicolumn{2}{|c|}{$\begin{array}{c}\text { Short } \\
\text { duration }\end{array}$} \\
\hline & Coeff. & $\mathrm{t}$ & Coeff. & $\mathrm{t}$ & Coeff. & $\mathrm{t}$ & Coeff. & $\mathrm{t}$ & Coeff. & $\mathrm{t}$ & Coeff. & $\mathrm{t}$ \\
\hline Training & $.751^{* * *}$ & 3.32 & 1.486 *** & 6.18 & $1.553 * * *$ & 8.28 & $.555^{* *}$ & 1.91 & $1.354 * * *$ & 4.09 & $1.161^{* * *}$ & 5.91 \\
\hline \multirow[t]{2}{*}{ Selection term } & $-.196 * * *$ & -2.44 & $-.482 * * *$ & -5.68 & $-.518 * * *$ & -7.58 & -.100 & -1.10 & $-.301 * * *$ & -3.06 & $-.400 * * *$ & -5.47 \\
\hline & \multicolumn{12}{|c|}{ Interaction terms } \\
\hline Primary & $-.178 * *$ & -2.32 & $-.162 * *$ & -2.24 & $-.242 * * *$ & -3.74 & -.015 & -.16 & -.184 & -1.56 & $-.162 * * *$ & -2.70 \\
\hline Secondary & -.118 & -1.12 & $-.246 * * *$ & -3.43 & $-.208 * * *$ & -2.91 & $-.280 * * *$ & -2.88 & $-.367 * * *$ & -2.78 & $-.150 * *$ & -2.34 \\
\hline Tertiary & $-.271 * * *$ & -3.26 & $-.339 * * *$ & -4.28 & $-.375 * * *$ & -5.31 & $-.247 * *$ & -2.19 & $-.464 * * *$ & -3.20 & $-.294 * * *$ & -4.82 \\
\hline experience $<6$ years & -.155 & -1.41 & $-.120 * *$ & -2.01 & $-.125 * *$ & -2.10 & -.095 & -.85 & $-.144 *$ & -1.65 & -.105 & -1.62 \\
\hline $\begin{array}{l}6 \text { years } \leq \text { experience }<26 \\
\text { years }\end{array}$ & -.014 & -.21 & $-.130 * * *$ & -2.67 & $-.122 * * *$ & -2.70 & -.048 & -.56 & $-.130 *$ & -1.67 & $-.094 * *$ & -2.06 \\
\hline Food, drinks and tobacco & .150 & .96 & -.039 & -.27 & .041 & .33 & $.245 * *$ & 2.36 & -.068 & -.54 & .143 & 1.12 \\
\hline Retail & -.162 & -1.35 & -.016 & -.20 & -.046 & -.58 & -.154 & -1.36 & $-.244 * *$ & -2.28 & -.008 & -.10 \\
\hline Wood and paper & .034 & .25 & -.073 & -.77 & -.016 & -.18 & .004 & .03 & -.242 & -1.16 & .064 & .61 \\
\hline Chemical products & -.143 & -1.04 & $-.237 * *$ & -2.08 & -.177 & -1.64 & -.180 & -1.20 & -- & -- & -.128 & -1.19 \\
\hline Metallurgy & -.014 & -.11 & -.104 & -1.27 & -.092 & -1.14 & $-.393 * * *$ & -3.31 & -.151 & -.99 & -.030 & -.36 \\
\hline Construction & -- & -- & $-.351 * * *$ & -2.50 & $-.410 * * *$ & -5.14 & $-.341 * * *$ & -3.28 & -- & -- & $-.302 * *$ & -2.09 \\
\hline Restaurants & $-.237 * *$ & -1.96 & $-.238 * * *$ & -2.54 & $-.218 * *$ & -2.36 & -.189 & -1.15 & $-.295 * *$ & -1.97 & $-.190 *$ & -1.93 \\
\hline Transports & .074 & .31 & -.036 & -.41 & -.019 & -.14 & $-.502 * * *$ & -3.62 & $-.278 *$ & -1.70 & .115 & .70 \\
\hline Insurance, finance & .137 & .98 & -.070 & -.63 & -.027 & -.27 & -.002 & -.01 & -.211 & -1.36 & .082 & .83 \\
\hline Public administration & -.045 & -.36 & -.096 & -1.37 & -.103 & -1.49 & -.085 & -.74 & $-.196 *$ & -1.79 & -.026 & -.36 \\
\hline Education & -.044 & -.37 & -.082 & -1.25 & -.068 & -1.07 & .008 & .06 & -.128 & -1.18 & .004 & .06 \\
\hline Health & .079 & .65 & -.078 & -1.09 & -.054 & -.76 & .094 & .74 & -.074 & -.66 & -.017 & -.23 \\
\hline Culture, sport, leisure & .123 & .74 & $-.243 * * *$ & -2.75 & -.061 & -.65 & $-.282 *$ & -1.90 & $-.290 * *$ & -2.37 & -.056 & -.49 \\
\hline Others & .232 & .15 & -.040 & -.51 & .045 & .58 & -.120 & -.92 & .0057 & .03 & .057 & .79 \\
\hline N. of observations & & & & & & & & & & & & \\
\hline
\end{tabular}

Notes: (i) * signals significant at the $10 \%$ level, $* *$ signals significant at the $5 \%$ level, and $* * *$ signals significant at the $1 \%$ level; (ii) the reference individual is an untrained worker with less than primary education, less than 6 years of tenure and experience, working full-time in the private sector, in a firm with more than 500 workers, in a commerce occupation, and in the North region of Portugal; (iii) control variables are included for region and quarter; (iv) standard errors are obtained using White's (1981) method; (v) in some cases, women in construction and chemical products occupations were dropped from the estimating sub-sample, for the incidence of one of the training categories within those occupations was exactly zero. 
Table 17: Transitions between employment and unemployment

\begin{tabular}{lllll}
\hline \hline & \multicolumn{2}{c}{$\begin{array}{c}\text { Exit from } \\
\text { unemployment }\end{array}$} & \multicolumn{2}{c}{$\begin{array}{c}\text { Entry into } \\
\text { unemployment }\end{array}$} \\
\hline \hline & Odd ratio & z-ratio & Odd ratio & z-ratio \\
\hline \hline Primary & .790 & -1.20 & .988 & -0.08 \\
Secondary & .875 & -0.56 & .736 & -1.56 \\
Tertiary & 1.068 & 0.17 & $.275^{* * *}$ & -3.92 \\
Experience & $.869^{* * *}$ & -7.27 & 1.018 & 1.20 \\
Experience squared & $1.001^{* * *}$ & 4.05 & $.999^{*}$ & -1.73 \\
Training & .692 & -1.41 & .791 & -1.06 \\
\hline \hline Pseudo R-squared & \multicolumn{2}{c}{0.1463} & \multicolumn{2}{c}{0.0193} \\
N. of observations & \multicolumn{2}{c}{1,237} & & \multicolumn{2}{c}{17,847} \\
\hline \hline
\end{tabular}

Notes: (i) * signals significant at the $10 \%$ level, $* *$ signals significant at the $5 \%$ level, and $* * *$ signals significant at the $1 \%$ level; (ii) the reference individual is an individual with less than primary education and no training, living in the North region of Portugal; (iii) control variables are included for region and quarter; (iv) standard errors are obtained using White's (1981) method. 


\section{Appendix A. Training Questions in the Inquerito ao Emprego, 1998-2000}

- Apart from formal schooling, have you completed any training scheme as a formation for a professional activity? $(1=$ yes, 2 = no)

- What type of training?

1. Vocational formation of tertiary level

2. Specific professional formation with one year or longer duration

3. Any training with less than one year duration

4. Other.

- Where did you receive this training?

1. University or college

2. Firm

3. Training center

4. Vocational school

5. Other.

- What was the objective of the training activity?

1. To help get started with a first job

2. To improve or update skills

3. To switch to another job or duties

4. Return to job after a long ausence ${ }^{24}$

5. Within a program of promotion of employment: initial training

6. Within a program of promotion of employment: continuous training

7. For personal interest

8. Other

- What profession did you receive the training for? (There are more than 50 branches, so we have regrouped the candidate answers into the following areas)

1. Health and life science

2. Teachers of primary, secondary and tertiary education, and related professions

3. Intermediate level technicians and professionals of physics, chemistry, engineering and mathematics

4. Specialists and technicians of scientific professions - other than physics, engineering and mathematics.

5. Firm directors and top rank workers of the Public Administration

6. Clerks and secretaries

7. Personal services, security and protection

8. Agricultural workers and fishermen

9. Workers of metallurgy

10. Workers of graphic arts, extracting industries, and civil construction

11. Other

\footnotetext{
${ }^{24}$ The number of this training event was zero.
} 


\section{Appendix B. Estimation by IV and quality of the instruments}

Table 1B. Instrument choice with tests of ortogonality and validity of the instruments

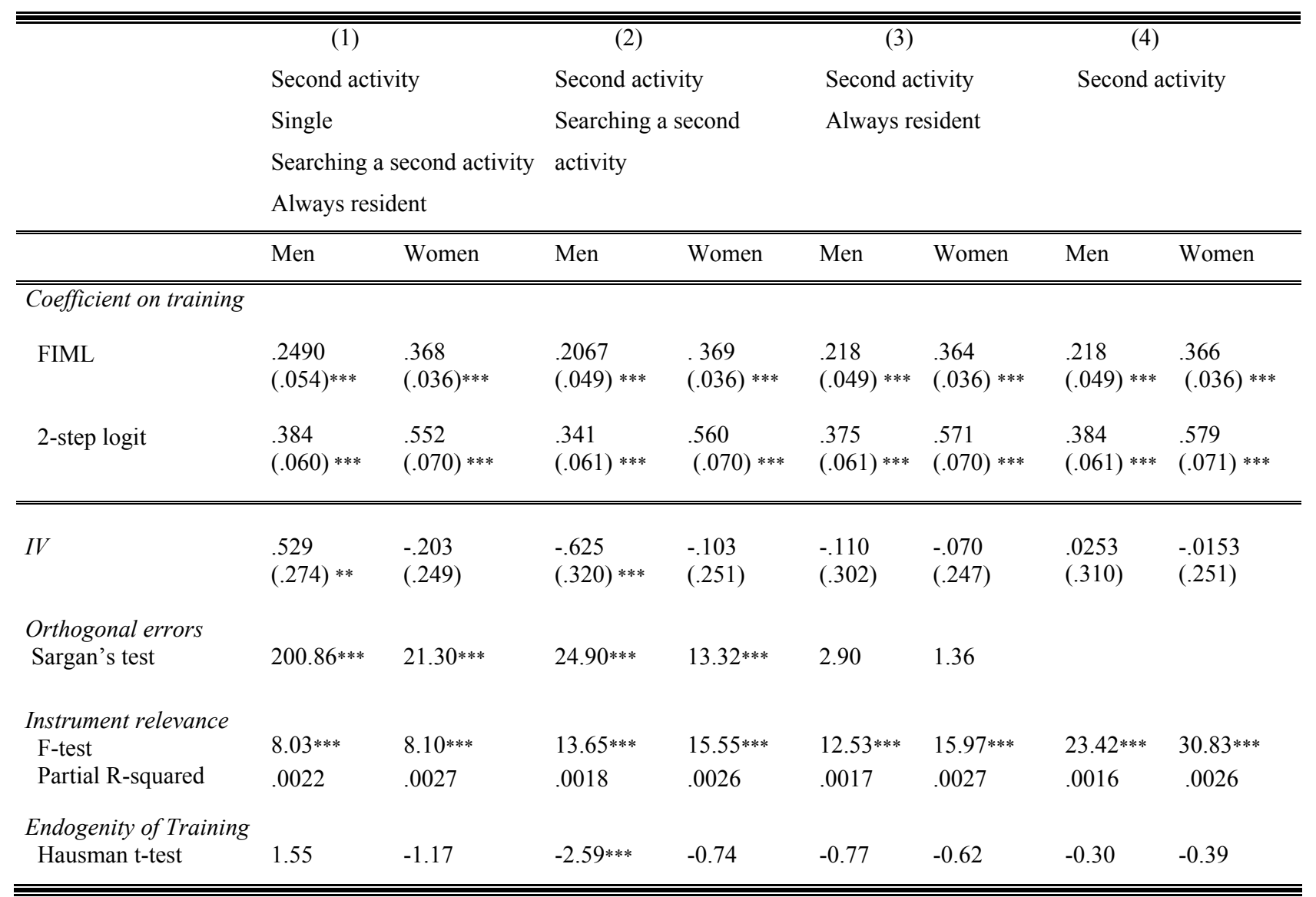

Notes to Table 1B: (i) Standard errors in parentheses, (ii) $* * *=$ significant at the $1 \%$ level, $* *=$ significant at the $5 \%$ level .

In this paper, we have used a treatment effects model to control for the endogeneity of training. In the first row of Table 1B we report the results under alternative specifications of the participation equation. Each column indicates the instruments that have been excluded (i.e., the set of instruments that have been included in the training equation but excluded in the wage equation). Interestingly, differences in the coefficient on training are very small. This finding gives us some confidence about the robustness of our results.

It is well known that the hypothesis test relating to the endogeneity of training can be extremely sensitive to the identifying variables used and this should always be borne in mind when conducting a test for selection bias. We need to interrogate the data carefully playing particular attention to the identifying instruments and the sensitivity of the estimated selection effects to alterations in this instrument set. Though not reported, we found that the selectivity term (the inverse of the Mill's ratio) is always significant among women and non-significant among men. We interpret this finding as evidence that training is a non-random event among women and a random event among men. Thus, simple OLS estimation is only appropriate for the male sub-sample. 
Our treatment effects model was estimated by maximum-likelihood (FIML). This approach estimates the participation equation (2) and the wage equation (4) simultaneously, which results in a more efficient estimation than the 2-step method á la Heckman. For comparability purposes, in the second row of Table 1B we have reported the results under the 2-step method. We find that returns to training tend to be sensitively higher and less precisely estimated under the 2-step procedure.

An alternative to our treatment effects approach is the instrumental variables (IV) approach. Estimation by IV assumes that some observable variables are a determinant of training participation but are uncorrelated with wages. It involves estimating the training participation equation in a first step and then using the predicted probability in the wage equation. It is well known that instruments should be valid, i.e., they must be uncorrelated (orthogonal) to the structural error. Otherwise, the estimates are likely to be biased and inconsistent. Moreover, instruments must be relevant, i.e., they must be sufficiently correlated with the endogenous regressor. Bound et al. (1995) have shown that a weak correlation between the endogenous variable and the instruments will exacerbate the problems associated with a correlation between the instruments and the structural error.

In Table 1B we compare IV estimates with those obtained with the model of treatment effects, and analyze to what extent changes in the set instruments affect the mean and the quality of the IV estimates. For each specification, we check the quality of the excluded instruments using the Sargan's test for orthogonality and the Bound et. al. test for the significance of the excluded instruments. We also report the Hausman t-test for the endogeneity of training participation.

In the first column, having a second activity, marital status, searching a second activity, and Portuguese residence are the excluded instruments. On the one hand, the treatment effects models (ML and 2-step) detect a positive and significant premium on training. On the other hand, the IV estimate indicates that training has a large and positive impact on wages only among men. However, the Hausman t-test rejects the hypothesis that training participation is exogenous. Therefore, according to the IV approach, the more efficient OLS estimation (which predicts a lower but significant premium on training) is preferred in this case. We find that the estimated coefficients are much less precisely estimated under IV than in the treatment effects model. Concerning the quality of the instruments, the F-test shows that the excluded instruments are jointly significant. Unfortunately, the Sargan's test warns that the error terms of the training and wage equation might be correlated and, thus, the IV estimates could be biased.

Column (2) shows that reducing the number of instruments does not necessarily solve the problem of orthogonality. Moreover, the sensitivity of the IV estimate to a small change in the set of instruments is somewhat disturbing. In the case of men, training exhibits a worrying negative and significant coefficient, while the Husman t-test suggests that the OLS estimation is likely to be biased.

In the following, we analyze two alternative models. In column (3) the set of excluded instruments has been restricted to pass the orthogonality test, while in column (4) the model is just identified. The F-statistics range from 12.53 to 30.83 . These values are highly significant and compare 
favorably to the criteria suggested by Bound et al. Moreover, comparing the partial R-squared in columns (1), (3) and (4) shows that using four excluded instruments does not change the explanatory power of the training equation by very much. Thus, the validity tests suggest that specifications (3) and (4) are not subject to finite sample bias. Under IV, we find that the coefficient on training is not statistically significant in either specification, which seems to contradict the predictions of the treatment effects model. However, the Hausman t-test does not reject the hypothesis that training participation is exogenous. Therefore, according to the IV approach, there is no evidence that OLS estimates are biased and estimation by IV is not needed.

To sum up, there is strong evidence that training has a positive and significant impact on wages. Under IV, rejection of the endogeneity of training suggests that estimation by OLS yields unbiased results. According to the OLS estimation, the average premium on training is about $12 \%$ among men and $8 \%$ among women. Moreover, the use of a FIML estimator indicates that the OLS estimates for the female sub-sample might be downward biased. Under FIML, the returns to training are as high as $37 \%$ among women. We also find that IV estimates are less robust and less precisely estimated than those obtained with a treatment effects model. As shown above, changes in the set of instruments can yield large changes in the estimated return to training in the IV estimates, while they have only a small impact on the coefficients of the treatment effects model. 